\title{
The Costs of Maintaining and Not Maintaining the Urban Forest: A Review of the Urban Forestry and Arboriculture Literature
}

\author{
Jess Vogt, Richard J. Hauer, and Burnell C. Fischer
}

\begin{abstract}
Existing urban forest literature is strongest in its quantification and qualification of the benefits and care of trees, and not in its ability to assess the results of lack of investment in trees. This paper presents the results of a literature review on the "Costs of Not Maintaining Trees" commissioned by the ISA Science and Research Committee. The authors summarized the literature from within the field of arboriculture/urban forestry to answer the questions: What are the costs of maintaining trees and the urban forest? And, What are the costs of not maintaining trees? Present here is a detailed summary of the literature on the costs of maintenance and lack of maintenance for types of tree care commonly included in municipal budgets (planting, pruning, removal, pest and disease management) and a brief review of costs associated with less-studied types of tree care (including tree risk management; watering; mulching; fertilizing and nutrient management; staking, cabling, and bracing; tree protection; and infrastructure repair). The authors suggest that future literature should aim to examine the influence of maintenance regimes on costs and tree outcomes, including examining how the frequency, intensity, duration, and extent of tree maintenance activities is connected to the structure, function, and benefits of trees.

Key Words. Cost of Not Maintaining Trees; Literature Review; Maintenance Costs; Pruning; Planting; Removal; Municipal Forestry; Deferred Maintenance; Urban Forestry; Urban Tree Maintenance.
\end{abstract}

The benefits of trees are frequently monetized and valued. Researchers and practitioners of urban forestry can put a value on the benefits of trees with reasonable ease, using the i-Tree software (or its precursors, STRATUM and UFORE, now the i-Tree Streets and Eco modules, respectively) and other direct or implied valuation methods [e.g., the Council of Tree and Landscape Appraisers (CTLA) valuation methods, replacement cost valuation, willingnessto-pay surveys, hedonic property value methods]. The value of these benefits is frequently then used to justify investments in trees (e.g., McPherson et al. 2005; Peper et al. 2009). Ideally, an economic analysis of urban tree benefits accounts for costs associated with planting through removal to create net benefit models (i.e., through benefit-cost analysis). Net benefits occur when benefits exceed the costs incurred to obtain these benefits.

The costs of urban tree maintenance and management are less understood. In a systematic review of studies that examine the benefits and costs of urban trees, Roy et al. (2012) found that only $15.6 \%$ (18) of 115 papers reviewed discussed the problems or costs of urban trees. The most common type of problem discussed was environmental (e.g., the release of volatile organic compounds), while explicit costs (e.g., money paid for tree pruning services) are most frequently monetized only in terms of budget outlays or expenditures by municipal urban forestry programs (Roy et al. 2012). Studies that examine the costs and benefits of the urban forest-in an attempt to calculate the net value of urban trees, for instance-frequently weigh municipal budgets ("costs") against the ecosystem services ("benefits") produced by public trees (e.g., McPherson et al. 2005; McPherson et al. 2006; Peper et al. 2009).

Tree maintenance funding at the municipal level is limited by the economic principle of scarce resources. There are only so many resources (e.g., money, time) available to allocate. Tree care budgets are frequently considered non-essential or less-essential city services when compared to police departments, fire 
departments, road projects, schools, and other public services. Thus, tree maintenance can frequently find itself on the chopping block during budgets. Sometimes, entire urban forestry programs are cut; for example, the entire urban forestry department of Gary, Indiana, U.S., was eliminated during the 2009 budget year as a result of the Great Recession (Krause et al. 2010). And this was not a new problem: a 1983 survey of 329 municipalities reported that the most commonly cited limiting factor to tree care was lack of funding (Tate 1984a).

Practitioners of urban forestry need tools to help determine minimally sufficient levels of spending on the provision and maintenance of trees in cities in order to meet diverse urban forestry program goals. With this in mind, the International Society of Arboriculture commissioned a literature review to examine "The Costs of Not Maintaining Trees." This paper is the second of three resulting from this literature review, and addresses the literature from within the fields of arboriculture and urban forestry (including municipal, commercial, and utility forestry), on the topic of tree maintenance costs. [The first paper was published in Arborist News in February 2015 (Hauer et al. 2015). The final paper will summarize tools and strategies from other fields that may help inform how arboriculture/urban forestry researchers and practitioners view the costs of maintenance.]

\section{LITERATURE REVIEW METHODS}

Researchers reviewed literature relevant to the costs of maintenance contained in the published records of the two main scholarly journals in the field of urban forestry-Journal of Arboriculture/Arboriculture \& Urban Forestry (JOA/AUF; 1975 to June 2013) and Urban Forestry \& Urban Greening (UFUG; 2002 to June 2013). To supplement the systematic reviews of $J O A / A U F$ and $U F U G$, researchers also performed keyword searches of scholarly databases to obtain literature from 1980 to June 2013 published in other major English-language journals related to arboriculture/urban forestry. Databases queried during the literature search included: Google Scholar ${ }^{\mathrm{ra}}$, Web of Knowledge ${ }^{\mathrm{rx}}$, JSTOR ${ }^{\circledast}$, SciVerse, and the University of Minnesota Urban Forestry Database.

Criteria for selecting articles for inclusion in the literature review included:

1. The article is within the discipline of urban forestry and includes discussion (qualitative) or measurement (quantitative) of a "cost" (monetary, opportunity, social, human, ecological, environmental, forgone benefit, etc.) or "benefit" (economic, social, human, ecological, environmental, etc.) resulting from some type of management of urban trees.

2. For articles not published in $J O A / A U F$ or $U F U G$, the article was published between January 1980 and June 2013.

3. The article was published in English, or at least an abstract was available in English.

4. Relevant review articles were included, and the relevant original research articles discussed therein were also consulted.

5. Opinion pieces (or opinion pieces billed as review articles - mostly from older issues of $J O A / A U F$ ) without references were included in the review, but were given less emphasis in qualitative summaries of topic areas.

6. Books (textbooks, reference books, and popular books) and book chapters were excluded from the literature search, except where these provided sources of peer-reviewed articles.

7. Professional whitepapers and government reports (e.g., those from the U.S. Forest Service or other appropriate entity) were included in the literature search, as long as they were scholarly in nature.

Selected articles (or their abstracts, if full text was unavailable) were added to a collaborative citations folder using the Mendeley citation software (Mendeley Ltd, New York City, New York, U.S.). Each article was read by at least one investigator and coded for the list of attributes in the Appendix using a Microsoft Excel $^{\circledR}$ spreadsheet.

\section{Dollar Values}

All dollar values presented in this text are in real values [current-day equivalent, expressed as 2013 dollars (U.S., Canadian, or Australian) or 2013 Euros], with nominal values (numeric dollars/Euros from the year the article was originally published) and year in parentheses (e.g., 1986\$). U.S. dollars were converted from nominal to real values using the U.S. Bureau of Labor Statistics Consumer Price Index inflation factors (BLS 2015). Canadian dollars were converted 
from nominal to real values using the Bank of Canada Inflation Calculator (BOC 2015). The single study from Australia that reported costs in local dollars (\$AUD) was conducted in 2013 (Ryder and Moore 2013) and required no conversion from nominal to real values. Euros were converted using European Union Consumer Price Index inflation factors for June 1 of beginning and end years (FXTOP 2015).

\section{The Logic of Linking Maintenance to the Benefits and Costs of Trees}

It is useful to think about the logic of how maintenance is linked to the benefits and costs of trees (Figure 1) before summarizing the literature on the costs of maintaining and not maintaining trees. Arborists and urban foresters intuitively know that the level of care or maintenance performed on a planted tree is linked to tree establishment, survival, growth, condition, and longevity (i.e., tree success). Survival, growth, and condition are closely connected to one another and to the structure of a tree (e.g., tree size, leaf area) and of the urban forest (e.g., canopy cover, diversity, age distribution). Tree structure, in turn, impacts the functions pro- vided by the urban forest and ultimately the level of benefits generated by the tree. Thus, less-thanoptimal maintenance may lead to decreased benefits produced by the urban forest (Figure 2, dashed lines). Theoretically, if one can determine how different levels of maintenance may differentially impact the level of benefits provided then he or she can determine the amount of benefits or value lost by reducing or eliminating maintenance. The benefits lost are the "costs" of not maintaining trees.

Note that because this literature review is not a comprehensive review of the benefits of trees, researchers have only included information about tree benefits as it has been connected in the literature to tree maintenance activities, lack of maintenance activities, or maintenance costs. The authors acknowledge that when trees are not planted or maintained properly and then die, benefits of all types these trees might have provided are lost-environmental, social, economic, or otherwise. In the literature review that follows, researchers include mention of specific types of benefits only when research has explicitly and quantifiably linked those benefits or loss thereof to a particular maintenance activity.

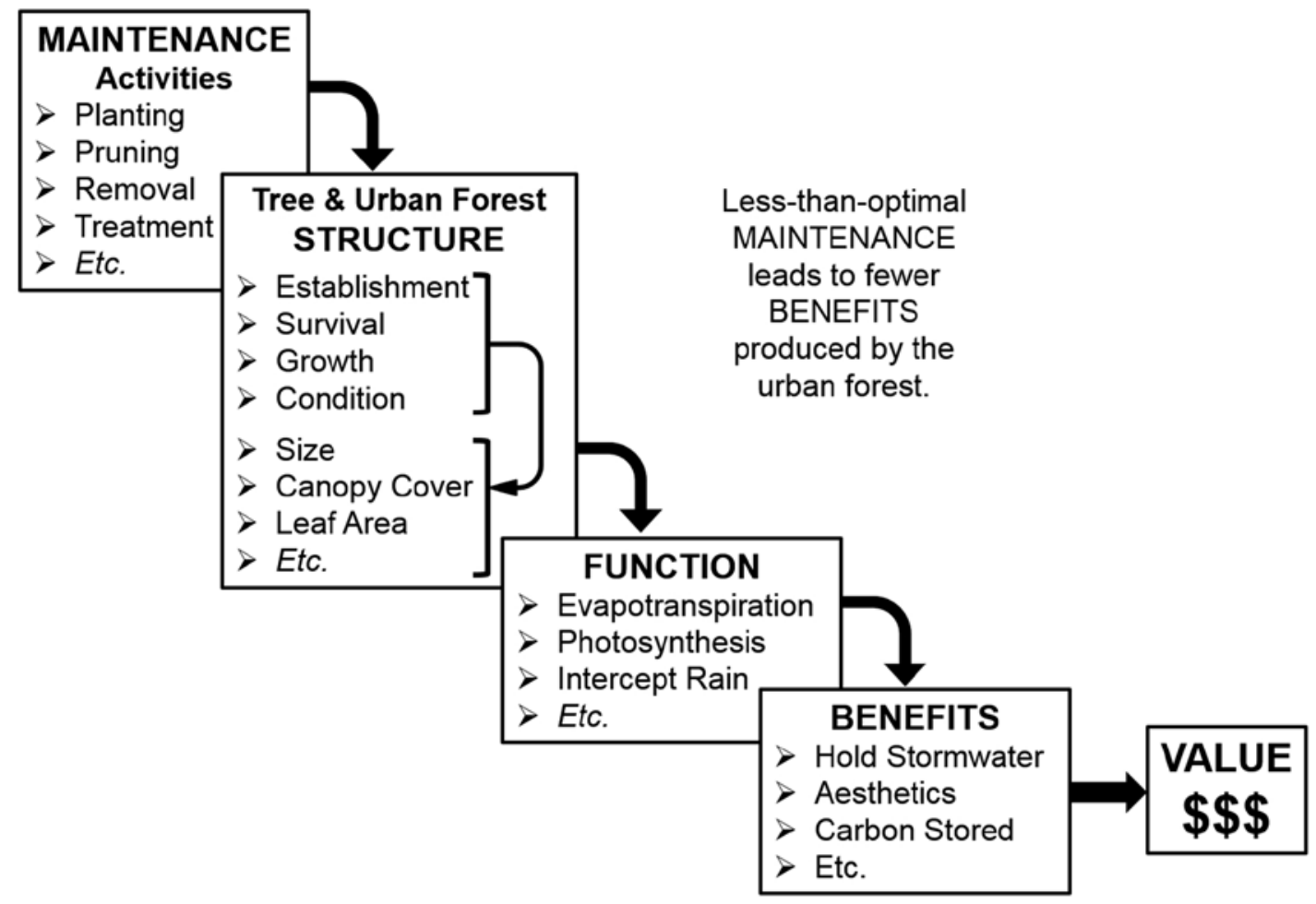

Figure 1. Maintenance directly impacts tree structure, which in turn impacts the functions and benefits provided by the urban forest. 


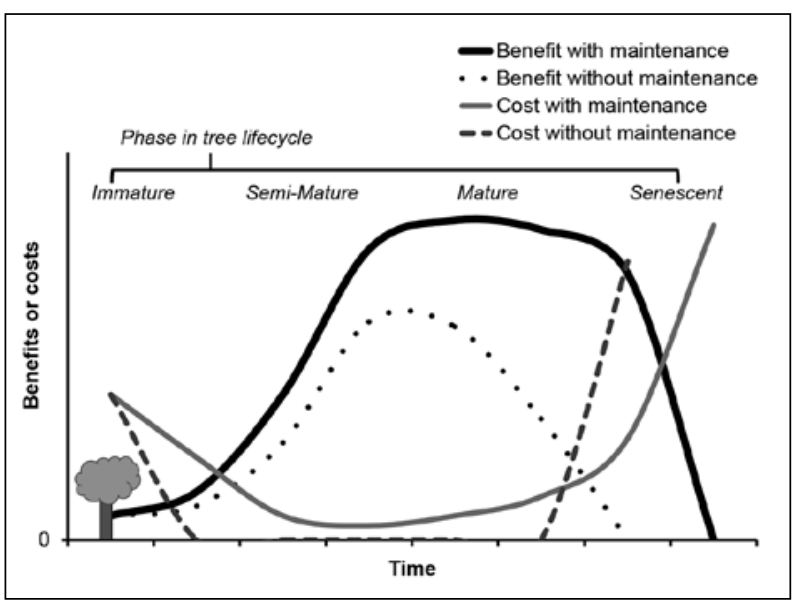

Figure 2. Hypothetical cost and benefit profiles over the lifetime of an individual tree (street tree), with (solid lines) and without (dashed lines) adequate maintenance. Benefits are maximized during the mature phase of a tree, and decline rapidly through senescence, while costs show an inverse pattern. Compare the benefits and costs profiles over the course of a tree's life cycle in this figure to the profiles over the tree size classes in Figure 5 . Note that the benefits and costs profiles for an individual tree will vary depending on the tree's location, the party benefiting from and incurring costs of the tree, and other factors (weather, etc.). Figure modified from Vogt et al. (2014).

\section{Maintenance throughout a tree's life}

Maintenance can be linked to tree success both at the beginning and end of its life span. Early in a tree's life, during the establishment and immature (i.e., juvenile) phases, maintenance must be adequate to ensure early survival and establishment in the urban landscape. Presumably, any post-planting maintenance performed on a tree that improves its chances of survival to maturity or lengthens the time that tree spends in its mature phase (where benefits are produced in the greatest amount) increases the monetary value of that tree (Figure 2). The cost of not maintaining trees early in life may translate to greater maintenance costs down the road; this is deferring maintenance (and its costs) to the future in order to save on maintenance costs today. Later in a tree's life, maintenance may aim to extend the tree's life span or prevent tree failure. In this way, late-stage maintenance can defer removal costs. For instance, structural pruning or crown thinning may aim to improve tree stability and reduce canopy weight and thereby reduce the likelihood of tree failure (although the research supporting this connection is not well documented; Clark and Matheny 2010). If maintenance does prolong a tree's useful life (i.e., delays the onset of senescence and a tree's removal), it increases the amount of benefits it produces over its life span. Alternatively, removing the dangling limbs on an aging tree can prevent these limbs from failing (during a wind storm or otherwise) and damaging people or property, and thereby avoiding subsequent repair- or liability-related costs (e.g., Bakken 1995). Tree pruning to remove high-risk limbs and removal of the entire tree can be considered a type of maintenance that purportedly can save money due to avoided litigation costs (depending on frequency, likelihood, and costs of litigation). The stylized benefits and costs curves presented in Figure 2 are in reality influenced by tree location, weather, pests/diseases, and many other factors both controllable and not controllable by people.

\section{Useful concepts from economics}

Translating tree maintenance into urban forest benefits can be informed by some key concepts from economics. Accounting for the costs and benefits of any activity - from a factory producing widgets to the ecosystem services produced by the urban forest-involves principles of effectiveness and efficiency. Efficiency is the optimal use of resources (inputs) to produce a given output, and can be qualitatively or quantitatively expressed, such as the number of dollars spent to prune trees per one-diameter-inch of trunk size. Effectiveness is less measurable, aiming considering whether what is done actually works and achieves an objective or outcome. Evaluation of efficient and effective use of resources also considers the element of time (when the maintenance occurred during a tree's life cycle), the changing value of money (e.g., due to inflation; see also the "dollar values" in METHODS), as well as risk and uncertainty in the use of resources (not to mention human willingness to accept risk and uncertainty). Researchers consider these concepts implicitly in the discussion of the literature that follows.

\section{RESULTS \& DISCUSSION}

\section{Summary of Publications Reviewed}

Over 300 articles were compiled, of which 163 were deemed useful for the literature review and included in the annotated bibliography and summaries 
here. In this section, researchers briefly summarize the themes from these articles, placing greatest emphasis on those that were found most helpful in elucidating the costs of not maintaining trees.

The cumulative number of articles published on the costs of maintenance from the two flagship journals in the field (JOA/AUF and $U F U G$ ) by year of publication is shown in Figure 3; the rate of publication of relevant articles is relatively constant over the last four decades. Other journals from which more than one article were reviewed include the Journal of Environmental Horticulture, Landscape \& Urban Planning, and Arboricultural Journal. Most articles discussed one or two types of maintenance, although some articles did discuss maintenance tasks in the aggregate or did not specify types of maintenance (Figure 4). Many articles reviewed did not examine costs in explicitly economic terms (59 articles) or only discussed inferred economic costs (34 articles). These inferred economic costs include articles that primarily focus on labor productivity or time-per-task (e.g., Pierce 1980 ), as this could be easily turned into monetary costs if the cost of labor were specified.

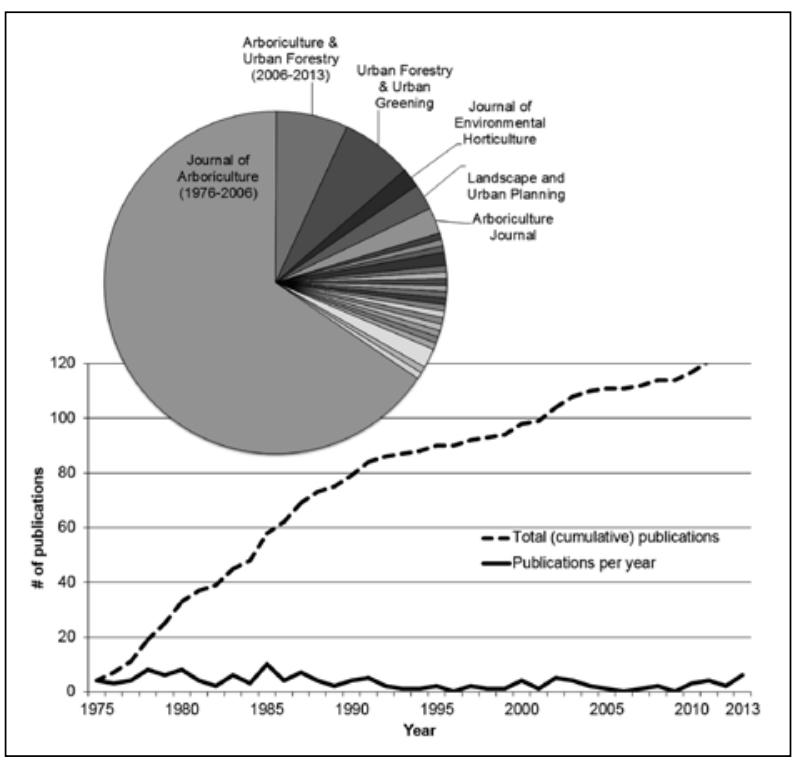

Figure 3. Sources of articles from within the field of arboriculture/urban forestry (inset pie chart) and the number of articles published per year (solid line) and cumulatively (dashed line) in the two flagship journals in the field, Arboriculture \& Urban Forestry and Urban Forestry \& Urban Greening related to the costs of tree maintenance.

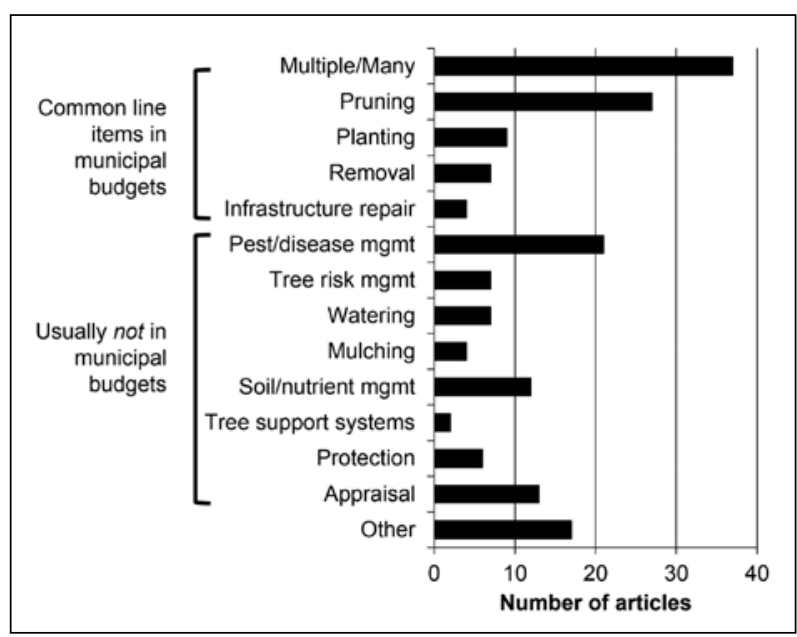

Figure 4. Number of articles examining each type of maintenance. Articles examining more than two distinct types of maintenance or in which maintenance activities were not disaggregated are designated Multiple/Many. Maintenance activities included in Other: staking, wrapping trees against salt or frost damage, inventorying, and forest (stand) management practices.

\section{What Are the Costs of Trees?}

In order to evaluate the costs of not maintaining trees, one needs to consider the benefits and costs incurred over the lifetime of a tree under different maintenance scenarios. Costs include the direct costs of provision and maintenance of urban trees, direct costs incurred as a result of infrastructure interference, costs inferred from environmental externalities, and opportunity costs (Table 1). The first three of these are summarized briefly hereafter; the latter is not discussed in the current urban forestry and arboriculture literature. Note that the costs of trees are the same neither for all types of trees (e.g., different species) nor for all types of planting situations (e.g., street versus park trees).

\section{Table 1. Types of costs in urban forests.}

\begin{tabular}{ll}
\hline Type of cost & Examples \\
\hline $\begin{array}{l}\text { Direct costs (of provisioning } \\
\text { and maintaining trees) }\end{array}$ & $\begin{array}{l}\text { Planting, pruning, watering, other } \\
\text { types of maintenance }\end{array}$ \\
$\begin{array}{l}\text { Infrastructure interference } \\
\text { costs }\end{array}$ & $\begin{array}{l}\text { Pavement and sewer repair, blockage } \\
\text { of signs, tree-initiated power outages }\end{array}$ \\
Externality-related costs & $\begin{array}{l}\text { Emissions of biogenic VOCs, release } \\
\text { of carbon dioxide during decompo- } \\
\text { sition, allergies due to pollen release, } \\
\text { leaf/debris clean-up }\end{array}$ \\
& $\begin{array}{l}\text { Space for trees cannot be used for } \\
\text { parking, bike lanes, etc. }\end{array}$ \\
\hline
\end{tabular}




\section{Direct costs associated with provisioning the urban forest}

Maintenance-related costs begin at the time of planting (also called installation costs) and continue throughout a tree's useful life through the time of removal. Maintenance costs vary throughout a tree's lifetime and by species and location (Schwarz and Wagar 1987; McPherson 2003; Leal et al. 2008). Planting and establishment costs can include the cost of purchasing the tree, any costs associated with reworking infrastructure around the tree (e.g., removing sidewalk or paving stones, modifying or amending soil in the planting space), the cost of labor to install the tree, and any subsequent at-planting maintenance, such as staking, pruning, mulching, or watering. Tree maintenance activities such as pruning, mulching, watering, and pest and disease management also occur throughout the lifetime of the tree and have costs during this time as well. Finally, during senescence, tree maintenance costs related to the removal of dead branches to reduce liability and risk and eventually removal of the entire tree could be substantial. This pattern of maintenance is what drives the theoretical costs throughout a tree's life cycle that are seen in Figure 2, and different levels of maintenance at different points in time may affect subsequent maintenance needs.

\section{Costs associated with tree interference with infrastructure}

Costs that result from infrastructure interference, damage, and repair are usually incurred when an improperly selected tree is used, the tree is not planted correctly, or is planted in an inappropriate location. Vegetation improperly located may block road signs, leading to vehicle accidents, or block business signs, decreasing visibility of a store. Sidewalk or street repairs are commonly observed for trees that are planted in too small of planting areas and thus their root systems damage the pavement (see section "Infrastructure repair"). Additionally, costs can be incurred due to lack of service resulting from tree-initiated power outages (e.g., a tree falling on a power line). Fire may result from tree contacts with electrical lines. Tree-caused power outages result in the costs of repairing the line and restoring service as well as cause lost electricity revenue during the outage (see section "Utility pruning costs"). Tree or branch failures also have costs in terms of roads blocked either due to the failed tree itself or to the tree crew cleaningup the failed tree or branch (Randrup et al. 2001).

\section{Negative externalities as costs}

Externalities are outcomes (benefits or costs) of a good or service that are not accounted for in the market price of that good or service. Most of the benefits of urban trees (e.g., stormwater management, aesthetic beauty) can be considered positive externalities. However, there are also negative externalities of trees. Costs related to the negative environmental externalities (occasionally called "ecosystem disservices," per Escobedo et al. 2011) of trees include net emission of biogenic volatile organic compounds (BVOCs) during the life of some tree species, leachate from foliar nutrients into surface water, as well as release of carbon dioxide and other greenhouse gases (e.g., methane) during decomposition at the end of a tree's life. Environmental costs can be related to the maintenance regime used by urban foresters taking care of an urban tree population. For instance, tree maintenance requiring the use of equipment (e.g., a front end loader, chip truck, aerial lift truck, wood chipper, or a chain saw) that burn fossil fuels releases of carbon dioxide into the atmosphere [see, for instance, Nowak et al. (2002), described in next section].

\section{Life cycle assessment of costs}

Life cycle assessment is one means of assessing the externality-related costs of urban trees that takes into account the entire life cycle of a tree from production (i.e., nursery) to removal and disposal. One common cost examined via life cycle assessment is greenhouse gas or carbon emissions resulting from urban forest activities. For instance, Nowak et al. (2002) examine the impact of minimal (lowcarbon), "conservative" (i.e., deferred), and "intensive" maintenance scenarios on the life cycle net carbon balance of planted urban trees: Minimal (low-carbon) maintenance involved no return visits after tree planting, while conservative and intensive maintenance scenarios involved pruning visits with chain saws, an aerial-lift truck, and a wood chipper every 15 and 7 years, respectively. Their analysis revealed that conservative and intensive maintenance had a negative impact on a tree's carbon budget, resulting in a decrease in the length of time 
between tree planting and the last positive point at which carbon sequestration no longer exceeded carbon emission (Nowak et al. 2002). Kendall and McPherson (2012) present a life cycle assessment that measures the greenhouse gas emissions of tree production. In the assessment, they consider all sources of emissions, including those associated with maintenance activities at the nursery, such as materials needed for staking, or nutrients used to amend soil (Kendall and McPherson 2012). In a similar analysis, McHale et al. (2007) investigate the carbon footprint of tree planting initiatives in the context of carbon credit markets. This article summarizes application of a set of guidelines for calculating carbon emissions and reductions associated with urban tree plantings to Colorado, U.S. cities to assess the cost effectiveness of tree planting in the carbon trading market (McHale et al. 2007). Maintenance is considered in two parts of their analysis: 1) in terms of emissions generated by "tree care activities" and 2) in total monetary costs of planting and maintenance over a 40 -year time frame ("how often the trees are watered, pruned, or fertilized, and whether or not volunteers are involved in these processes") (McHale et al. 2007, p. 52). However, as maintenance rates were fixed and were not examined as part of the analysis performed with either Kendall and McPherson (2012) or McHale et al. (2007), researchers cannot compare estimates of emissions costs between maintenance scenarios. Other authors have examined the costs of urban greenspace more generally using a life cycle approach (e.g., Jo and McPherson 1995; Jo 2002; Strohbach et al. 2012).

\section{Costs not considered in current literature}

Some costs of urban trees are largely ignored in the current literature. Commonly omitted costs include those incurred for leaf collection and the release of biogenic volatile organic compounds into the atmosphere. Where BVOC release is included as a "cost," it is usually included in the estimation of air pollution or emissions reductions rather than itemized as its own cost (e.g., McPherson et al. 2006). Pollen release from trees may exacerbate costs of allergies and medical treatments. A final important omitted cost is the opportunity cost of alternative land uses for the tree planting location. When trees are planted in the public rightof-way, the space cannot be used for other things, such as an outdoor café, a bike lane, parking, or additional lanes of traffic (Loukaitou-Sideris 2011).

\section{Assessing the costs of not maintaining trees} Ryan (1985) was one of the only authors to explicitly mention the costs of not maintaining trees in light of municipal tree budgets: “. . . trees that are not maintained at regular intervals soon become hazards due to deadwood and windthrow. This cannot only upset your budget but may also cause considerable loss of life and property" (p. 114). In the paper, Ryan presented a dialectic for construction of a municipal tree maintenance budget and claims that both the "Estimated Cost of NOT Doing Tree Work" (emphasis original) and the "Estimated Savings by Doing Work" are important parts of justifying budgets (Ryan 1985). However, this article provides no specific suggestions for how to estimate these costs. Ryan (1985) argued that urban trees should be considered part of urban infrastructure (as what is, in modern terms, "green," or living, infrastructure, to contrast with grey infrastructure, such as roads and sewer systems), and uses this idea to describe how the benefits of trees can be used to help justify costs of city tree budgets. In a related article published in the Journal of Arboriculture, Schwarz and Wagar (1987) asked, "how much should you spend now [on street tree maintenance] to save later?" These authors presented three accounting frameworks that can be used to determine when preventative maintenance can result in decreased overall tree maintenance costs (Schwarz and Wagar 1987). However, the methods presented (discounted present value of future benefits, internal rate of return, and service-life extension value or useful-life value) require that maintenance needs in the future be estimated (Schwarz and Wagar 1987), and the article did not provide guidance on how exactly to predict maintenance needs or estimate what they might cost; the authors also choose a discount rate that has large impacts on the conclusions of the study.

\section{Maintenance Commonly Included in Municipal Budgets}

Costs of trees are frequently expressed in terms of expenditures by the parties who commonly pay for the care of trees. O'Bryan et al. (2007) estimated that the private arboriculture industry (excluding municipalities, nonprofits, or other non-commercial firms, 
and excluding utility arboriculture) collected nearly USD \$9 billion in gross receipts in 2002 (although this analysis is unable to disaggregate this figure into types of tree care or maintenance). Municipality expenditures on maintenance are more easily disaggregated by type: the most well-established types of tree maintenance activities-planting, pruning, removal, infrastructure repair, and pest/disease management-frequently appear as line items in city budgets (Kielbaso et al. 1982; Kielbaso 1990; Tschantz and Sacamano 1994; Kenney and Idziak 2000), while items like watering and mulching appear far less frequently (e.g., Thompson et al. 1994). Municipal costs are also commonly reported in benefit-cost analyses (studies that compare the costs and benefits of urban forests (e.g., McPherson et al. 1997; McPherson et al. 1999; Maco and McPherson 2003; McPherson 2003; McPherson et al. 2005; Millward and Sabir 2010; Roy et al. 2012). For example, McPherson (2003) reported on the size-specific maintenance costs for planting, pruning, removal, root-related infrastructure repair, pest management, and liability associated with 10 species of street trees in Modesto, California, U.S. (results reproduced in Figure 5).

Surveys of municipalities in the United States (400 municipalities: Kielbaso et al. 1982; 1,534 municipalities: Kielbaso 1990; 419 municipalities: Tschantz and Sacamano 1994), in Canada (92 municipalities: Kenney and Idziak 2000), and in Santiago, Chile (Escobedo et al. 2006) have reported on the total tree-related expenditures of municipal governments. In the United States, tree expenses were distributed among street trees (61\%) and park trees (24\%; Kielbaso et al. 1982), and as a whole accounted for less than one-half of one percent of total city budgets (Kielbaso 1990). Average annual per-capita municipal tree expenditures in the United State were $\$ 7.70$ in 1974 ( $\$ 1.63$ in 1974\$; Kielbaso 1990), \$6.19 in 1980 (\$2.19 in 1980\$; Kielbaso et al. 1982), and \$5.53 in 1986 ( $\$ 2.60$ in 1986\$; Kielbaso 1990). Annual per-tree expenditures were $\$ 30.48$ in $1980 \$(\$ 10.78$ in 1980\$; Kielbaso et al. 1982) and \$22.57 (\$10.62 in 1986\$; Kielbaso 1990). Kenney and Idziak (2000) conducted a survey of Canadian municipalities between 1996 and 1998 and reported that average expenditures on tree maintenance were CAD $\$ 3.00$ per capita and CAD $\$ 23.55$ per tree annually $(\$ 2.20$ and $\$ 17.29$, respectively, in $1997 \$$ ). Escobedo et al.
(2006) report results of expenditures by Santiago's regional government on "green area management," finding that municipality-level spending varied from $\$ 27,366$ to $\$ 1,628,304$ ( $\$ 16,000$ to $\$ 952,000$ in $1991 \$)$ per year, while per-tree maintenance costs ranged from $\$ 0.17$ to $\$ 6.84$ ( $\$ 0.10$ to $\$ 4.00$ in $1991 \$$ ).

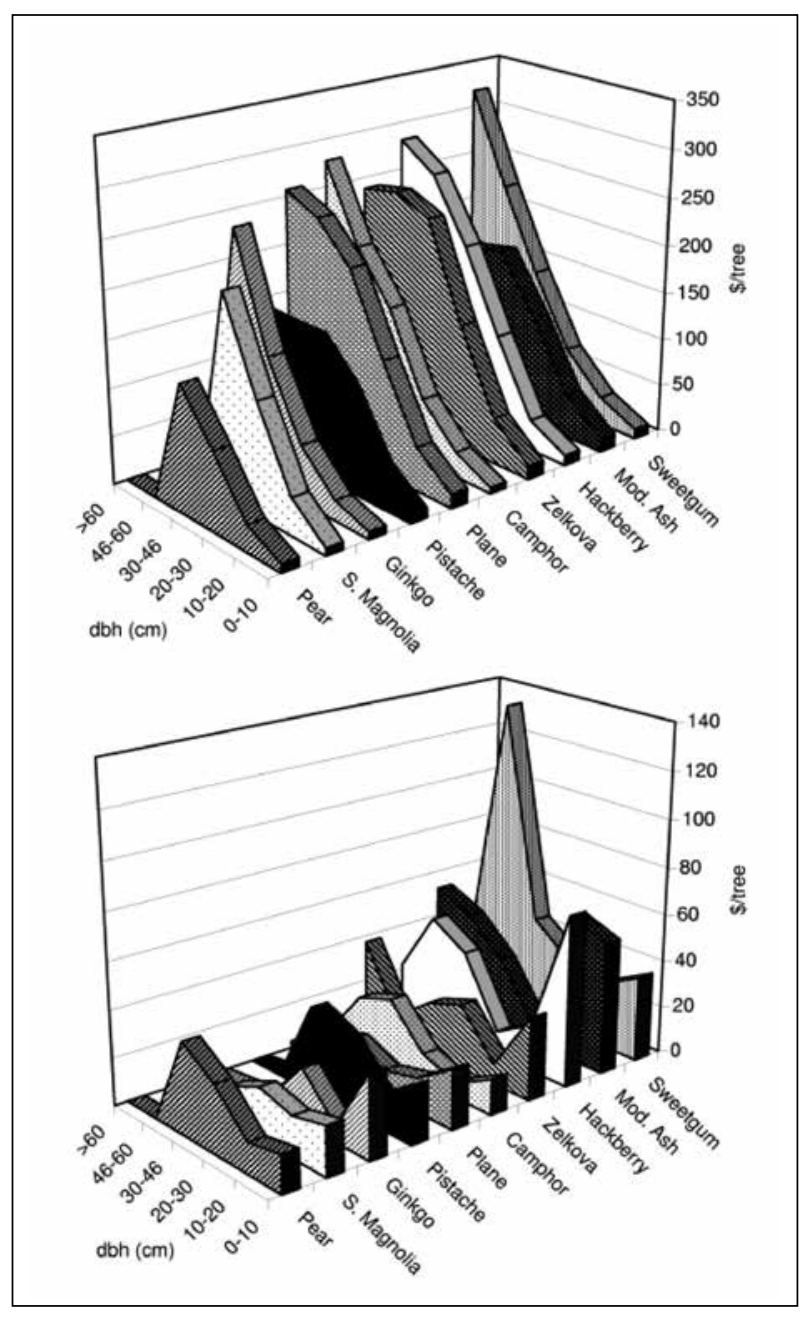

Figure 5. Tree value increases as the size of trees increase (top). The cost of tree maintenance varies by life stage of tree and maintenance requirement (bottom). Figure reprinted from McPherson (2003).

\section{Pruning}

Of all urban forest maintenance activities, pruning is the most studied in terms of economics. Pruning is performed throughout the lifetime of a tree for various reasons, including: improving growth form (Evans and Klett 1985; Ryder and Moore 2013); alleviating structural problems, such as removal of deadwood (Hensley 1979); crown raising (Clark and Matheny 2010); and manag- 
ing pests or diseases (e.g., Dutch elm disease: Himelick and Ceplecha 1976; Gregory and Allison 1979; Sherald and Gregory 1980; Baker and French 1985; see section "Pest and disease management"). Pruning costs are related to the type (and goals) of pruning performed (Ryder and Moore 2013).

\section{Municipal pruning costs}

Tree pruning costs are typically the most expensive maintenance item in municipal tree programs (Kielbaso et al. 1982; Kielbaso 1990; Tschantz and Sacamano 1994). Surveys in 1980 and 1986 reported that pruning accounted for $28 \%$ and $30 \%$, respectively, of the municipal tree care budgets of U.S. cities (Kielbaso et al. 1982; Kielbaso 1990). Tschantz and Sacamano (1994) reported that tree pruning accounted for an average of $36.9 \%$ of tree care operations costs and mean pruning expenses were $\$ 130.04$ per tree (\$82.73 in $1994 \$)$. In a benefitcost analysis for 10 street tree species in Modesto, California, U.S. McPherson (2003) reported that pruning was the greatest category of maintenance costs for all species, ranging from \$91 (\$63 in $1997 \$$ ) per tree pruned for London planetree (Platanus acerifolia) to \$328 (\$226 in 1997\$) per tree for Modesto ash (Fraxinus velutina 'Modesto').

Privatizing tree care operation is often suggested as a method to reduce costs through potential efficiencies (e.g., shared equipment and labor costs across multiple jurisdictions) that the private market place may bring into the public sector (Diller 1975; Tate 1986; Tate 1987; Tate 1993). The data to support this was not found in peer-reviewed papers. New York City, New York, U.S., found contracting to improve flexibility and efficiency of tree care operations (Lough 1991). Similarly in Los Angeles, California, U.S., contracting tree-trimming services in combination with in-house staff was found to facilitate shifting from a 16.5- to 6-year tree pruning cycle (Kennedy 1990). As reported in a local newspaper at the time, the City of Saint Paul, Minnesota, U.S., put the tree pruning operations out for bid and found the city workforce submitting the lowest bid of $\$ 35.64$ per tree ( $\$ 25.49$ in $1999 \$$ ) in comparison to private firm bids ranging from $\$ 53-\$ 144$ per tree (\$38-\$103 in 1999\$) (Duchschere 1999). A key to successful incorporation of private contractors is developing definitive specifications that are inspected for compliance and enforced by city staff;
Henning (1990) and Klonowski (1991) provided mechanisms to evaluate contractor performance.

\section{Worker efficiency studies}

Even though tree pruning typically receives the greatest budget allocation of all municipal tree maintenance activities, it is still often underfunded in comparison to needs (Sievert 1988). For this reason, efficient allocation of resources for pruning is important. Tracking worker activities, productivity, and performance over time (per O'Brien and Joehlin 1992) could help develop models of speciesand size-specific required pruning time and estimate pruning time for future work while allocating maintenance resources appropriately (O'Brien et al. 1992). The size of the tree was found to be positively correlated to the time required to prune, for dispos$\mathrm{al}$, and the amount of woody debris collected during pruning operations (O'Brien et al. 1992; Churack et al. 1994; Zillmer et al. 2000). Thus, maintenance needs and costs of trees increase as the size of the tree increases (Miller et al. 2015; Nowak 1990).

From an early work in the 1960s, Wagner (1970) reported that a three-person crew was most efficient, requiring 54 work-minutes per trim in comparison to 59, 100, and 141 minutes for four-, five-, and six-person crews performing utility line pruning. In comparison, Overbeek (1979) reported that the City of Grand Rapids, Michigan, U.S., found a four-person crew to be most efficient. The challenge is to maximize worker productivity by developing standards for different operations and collecting data that can be used to make management decisions. Pierce (1980) reported that crews in Omaha, Nebraska, U.S., spent $36 \%$ of work time on pruning activities (although no information is provided on the size of the urban forest maintained by tree crews).

Churack et al. (1994) authored the first study to describe through mathematical formulas the time requirements for pruning tree species in Milwaukee, Wisconsin, U.S. They found a strong positive relationship between pruning time required and tree diameter for four common species: green ash (Fraxinus pennsylvanica), honeylocust (Gleditsia tricanthos), littleleaf linden (Tilia cordata), and Norway maple (Acer platanoides) (Churack et al. 1994). Waste wood stack time and waste wood yield were also quantified, as were trends similar to that as discovered with pruning time were discovered for 
the four species (Churack et al. 1994). Zillmer et al. (2000) presented an updated productivity timing system for tree climbing training in Milwaukee, Wisconsin, U.S. The application of this technique in other regions would yield robust estimates of costs of pruning municipal tree populations, when combined with tree growth rates, tree population characteristics (e.g., tree size and tree species), and labor costs.

\section{Utility pruning costs}

Pruning is performed extensively by utility companies and many articles discussing the economics of pruning are from a utility forestry perspective. O'Brien et al. (1992) reported that pruning takes longer for trees under utility wires. The cost of not pruning around utility wires or poles is clear: a lack of tree pruning can result in tree or branch failures or interference with utility lines (e.g., phone, electricity, cable, internet) during storm events, resulting in costly clean-up, repair, lost customer billing time, safety issues resulting in human injury or death, and more (Medicky 1976; Perry 1977; Dykes 1980; Ulrich 1983; Johnstone 1988; Kuntz et al. 2002; Guikema et al. 2006). Utility pruning, therefore, is frequently examined in the context of "what can be purchased by budget expenditures for tree trimming in terms of reliability" (Perry 1977, p. 157). Concepts like the "minimum permissible clearance" distance between tree branches and utility infrastructure (Medicky 1976, p. 56), pole-miles of line maintained (Ulrich 1983), "optimal" maintenance scheduling algorithms (Kuntz et al. 2002), and other performance criteria [e.g., cost-effectiveness of pruning efforts (David 1979; Holewinski and Johnson 1983); time efficiency (Henning 1990)] infuse the utility pruning literature. Ultimately, utility companies have a strong economic incentive (i.e., profit margin) for optimal allocation of resources toward pruning efforts. Avoiding fines for electrical outages also factors into resource allocation.

Authors who have most comprehensively examined the costs of deferring utility pruning include Browning and Wiant (1997), Kuntz et al. (2002), and Goodfellow and Kayihan (2013). Browning and Wiant (1997) analyzed the time and costs of pruning utility trees in terms of time per tree as time varies by several factors, including time since last pruning, pre-work clearance distance, branch length, time of pruning, and tree diameter. Results indicate that for each additional year maintenance is deferred past the optimum pruning cycle length, USD \$1 saved now will have to be replaced by $\$ 1.47-\$ 1.69$ of spending four years in the future, and will yield approximately twice the amount of pruning waste for disposal (Browning and Wiant 1997). Kuntz et al. (2002) presented a "quantitative approach to maintenance scheduling" aimed at reducing the cost of maintenance activities and increasing the reliability of utility service (p. 1164). The authors used an optimization problem approach to minimize or maximize one of three objective functions with respect to maintenance crew availability: minimize total cost of reliability, minimize cost per a given reliability, or maximize reliability for a given cost (Kuntz et al. 2002). The cost of reliability was estimated as customer willingness-to-pay to avoid a power outage; the cost of maintenance efforts was computed as cost per mile of line maintained (Kuntz et al. 2002). Results indicated that computeroptimized maintenance schedules improved the interruption frequency index (a measure of utility system reliability where greater index values indicate better performance) by $4 \%-6.5 \%$ over a fixedinterval maintenance schedule (Kuntz et al. 2002).

Most recently, Goodfellow and Kayihan (2013) conducted a comprehensive review of the models used in scheduling utility pruning and identified five commonly used models: clearance, cost of deferral, reliability, annual increment, and regulatory mandate. These authors then presented a probability-based "bow-tie analysis" model that weighs an acceptable level of risk against a desired level of performance in assessing causes and consequences of an incident (Goodfellow and Kayihan 2013). In this light, preventative maintenance measures impact the likelihood of an incident occurring (i.e., tree failure and power system interruption), which mitigating maintenance efforts impact the relationship between the incidence and the consequence or result that occurs. The authors identified a suite of variables that can be assessed in examining and weighing risk; see Goodman and Kayihan (2013) for the complete literature review and model.

Utility rights-of-way also employ chemical means of controlling growth and form of trees near utility wires. Several authors in the late 1970s and early 1980s examined chemical growth control (Olenick 1977; Carvell 1975; Domir 1978; Domir and Rob- 
erts 1983). Flurprimidol provided effective growth reduction; however, stem cracking, wood discoloration, and injection site weeping led to the discontinued use (Miller and Abbott 1990; Chaney 2005). Paclobutrazol currently is used for tree growth reduction through a soil application (Bai et al. 2004). Costs figures are not provided for any of these studies.

Interestingly, the cost of not properly maintaining or planting trees near houses and buildings also means that the energy savings that would result from a mature tree may be forgone (e.g., due to early removal); therefore, a utility company may have to install new electricity-generating infrastructure or increase capacity to cope with peak demand for electricity (rather than maintaining trees near buildings, which would offset peak demand (McPherson et al. 2006; Donovan and Butry 2009). Trees planted and maintained on the west side of a house were found to provide annual cost savings of USD \$15.50 (4\% discount rate) over a 50-year period (Donovan and Butry 2009).

\section{Pruning cycles}

Increasing the length of the pruning cycle, or the number of years between pruning events, is a way to reduce pruning costs up front. In the short term, deferring the cost of pruning solves the immediate problem of a limited budget. However, future costs will likely be greater from increased responses to citizen service requests, storm damage susceptibility, reduced condition class, tree risk from deadwood, rubbing branches leading to wounds, and more. Structural defects (e.g., decay, poor branch attachments, deadwood, cracked branches) become more frequent as the numbers of years since last pruned increases (Miller and Sylvester 1981; Luley et al. 2002). Reducing these factors along with structural pruning of trees from a young age are considered factors that make trees more resistant to failure during ice storms (Hauer et al. 1993, Sisinni et al. 1995). Luley et al. (2002) compared service requests, priority maintenance work, and incidence of branch failures in street tree management areas that had been pruned or not pruned in the last five years. They observed less priority maintenance work in recently pruned areas, but did not perform a complete economic analysis to compare cost savings resulting from less priority maintenance to the costs of frequent pruning (Luley et al. 2002).

The relationship between pruning frequency and tree failure may be less clear in rural areas than for street trees. Kane (2008), however, found that campsite tree failure during a wind storm was unaffected by whether a tree had been recently pruned.

Ultimately, the length of pruning cycle impacts the condition class ratings of trees. Miller and Sylvester (1981) developed a curvilinear model that related the condition of street trees to the number of years since last pruning in Milwaukee, Wisconsin, U.S. (Figure 6a). The optimal pruning cycle was based on the value of the tree resource in relation to
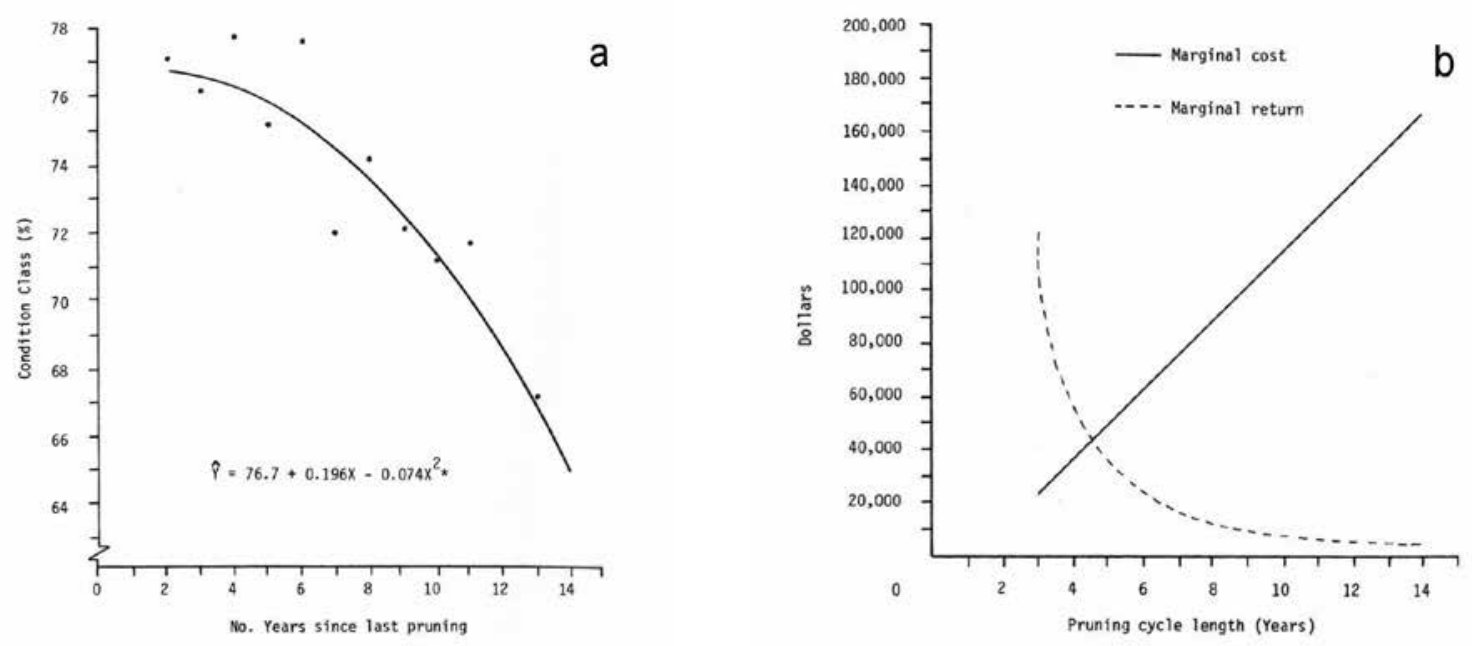

Figure 6. a) Relationship between pruning cycle length (number of years since last pruning) and CTLA condition class rating. Asterisk $\left({ }^{*}\right)$ indicates regression is significant at the $\mathbf{0 . 0 5}$ level. b) Marginal cost (loss of tree value) and marginal return (savings in pruning costs) for pruning cycle lengths. Figure reprinted from Miller and Sylvester (1981). 
changes in pruning costs and condition class (Miller and Sylvester 1981). Cost was generated as the reduction in tree value as condition class declined for each one-year increase in the pruning cycle length; marginal return, or marginal benefit, was generated based on the net decrease in pruning costs as the pruning cycle was increased in increments of one year (Miller and Sylvester 1981). Comparison of savings in pruning costs versus reductions in tree population value suggested the optimal pruning cycle to be between four and five years (Figure 6b).

\section{Costs of not pruning}

The costs of not pruning trees have rarely been examined outside of the context of utility arboriculture or pruning cycles. The only study this literature review found that explicitly examines this question is Ryder and Moore (2013, see sidebar The Costs of Not Pruning).

\section{The Costs of Not Pruning}

Ryder and Moore (2013) have authored one of the few papers that explicitly examine the costs of not maintaining trees (i.e., deferring maintenance). These authors asked: "If a tree is formatively pruned in the early stage of life, what will the cost-saving be if the same defects had not been rectified?" (p. 17). Seventy-eight percent of all planted trees in their sample showed structural defects that required formative pruning (Ryder and Moore 2013). Formative pruning costs (all currency is in AUD\$) averaged $\$ 2.79$ per tree, while structural pruning for a mature tree averaged $\$ 44.59$ (Ryder and Moore 2013). The authors estimated that using inflation rates of $3 \%-5 \%$, trees not formatively pruned today would cost $\$ 78$ to $\$ 112$ to structurally prune in 20 years (Ryder and Moore 2013). Thus, the cost of not performing formative pruning on recently planted trees can be calculated as the difference between the costs of formative pruning plus normal structural pruning $(\sim 48)$ and structural pruning for non-formatively pruned trees (\$78-\$112), or between $\$ 30$ and $\$ 64$.

\section{Planting}

Kielbaso et al. (1982) and Kielbaso (1990) attributed $14 \%$ of city forestry budgets expenditures to planting costs (the cost of the tree, labor, materials, water, mulch, and other things at time of planting). Tschantz and Sacamano (1994) reported planting at $13.9 \%$. Time-of-planting costs can account for $80 \%$ or more of total maintenancerelated costs during the life of a tree (McPherson et al. 1997). Pauliet et al. (2002) reported results from a survey of cities in 17 European countries that revealed street tree planting and establishment costs range widely from EUR $€ 250$ to $€ 1,875$ (200-1,500 in 2002€). McPherson (2003) reported that planting and establishment costs vary by species, and range from USD $\$ 0.01$ annually per tree for hackberry (Celtis sinensis) (\$0.01 annually in $1997 \$$ ) to $\$ 3.16$ annually per tree for ginkgo (Ginkgo biloba) (\$2.18 annually in 1997\$).

McPherson et al. (1997) and others have argued that time-of-planting costs can be reduced significantly by properly matching the tree to the site, which calls to mind the urban forest management axiom: right tree, right time, right place. Planting and establishment practices can influence subsequent maintenance needs and costs. Harris (1985) argued that adequate root conditions for healthy establishment could make trees easier to maintain later in life. Chapman (1981) specified that proper tree selection could reduce annual maintenance costs "by 20 to 50 percent" (p. 316), a significant potential savings where maintenance costs can range "from 20 to 50 percent of the planted price" (p. 313); however, Chapman provided no numerical data to support purported monetary savings. McPherson (1992) stated that "funds spent initially to promote tree establishment, rapid growth and strong crown structure can reduce long-term tree care costs by prolonging the serviceable life of the tree" (McPherson 1992, p. 47); however, this article provided no long-term data to back this conclusion. McPherson (1992) suggested a specific accounting approach for treeplanting projects, and demonstrates the utility of the approach using the city of Tucson, Arizona, U.S. The author found that costs of planting initially exceed the benefits of planted trees, but within five years of planting, benefits exceed costs at a rate of 3-to-1 or greater (McPherson 1992). 


\section{Costs of not planting}

The costs of not planting trees have been explicitly quantified in only a few studies. McPherson (2001) quantified "benefits forgone" (e.g., airconditioning savings, stormwater management) to express the difference between the current level of shading benefits provided by trees on parking lots in Sacramento, California, U.S., and the benefits to be expected if all parking lots conformed to the $50 \%$ shaded area required by ordinance. This "benefits forgone" metric can be interpreted as the cost of not planting trees, equal to USD \$1.9-3.4 million annually as calculated in this study (\$1.4-2.5 million in 2000\$; McPherson 2001). However, McPherson (2001) notes that this figure is strictly benefits forgone, rather than net benefits forgone, and does not include the full costs associated with planting and maintaining the greater number of trees to provide benefits (e.g., repair to pavements due to tree damage). Miller and Morano (1984) also provided data that enables calculating the costs of not planting trees (see sidebar The Costs of Not Planting).

\section{Removal}

Tree removal is a tree maintenance activity necessitated by a variety of circumstances in urban areas: failure to establish in the landscape; old age; pest or disease attack; construction of roads or buildings; ice, wind, or other storm damage; risk that exceeds what managers are willing to accept; and more (Nowak 1990). Tree removal is often the second-most costly expense for municipal tree program operations after pruning (Kielbaso et al. 1982; Kielbaso 1990; Tschantz and Sacamano 1994). Kielbaso and colleagues reported that tree and stump removal accounted for $28 \%$ of the municipal tree budgets on average in 1980 (Kielbaso et al. 1982) and 1986 (Kielbaso 1990). Tschantz and Sacamano (1994) reported an average of $20.1 \%$ of the tree care budget was allocated solely for tree and stump removal. In a benefit-cost analysis by McPherson (2003), removal costs ranged from $26 \%$ of total tree costs for ginkgo (mostly due to high mortality rates during establishment) to $2 \%$ for Modesto ash and sweetgum trees.

\section{The Costs of Not Planting}

In a 1984 article in Journal of Arboriculture, Miller and Morano presented a computerized urban forest management simulation or game designed to model changes in a street tree population over time as a result of maintenance activities. The program, entitled URFOR/SIMULATION, used actual street tree data from a city in Wisconsin, U.S., and allowed a user to select management plans to set planting, pruning, and removal rates (Miller and Morano 1984). The simulation ran on an annual basis for the number of years specified by the user, and the program output described the impact of management plans on the street tree population, calculated the value of the trees, and summarized management costs. The simulation also included the ability to introduce any of six random events: wind storm, ice storm, new disease, drought, budget increases, and budget cuts. Data from an example simulation presented in Miller and Morano (1984) illustrated the impact of planting on the net value of trees in the urban forest. While a fully-stocked urban forest was initially the most costly management scenario, over the 40-year run of the simulation, it resulted in the greatest net benefits (see Figure 7). The difference between the fully-stocked or repacement scenarios and the no-planting scenario can be interpreted as the costs (benefits forgone) of not planting trees. The URFOR/SIMULATION program was a DOS-based program. CityTrees! Lite v1.0 is an updated version that operated under Microsoft Windows 3.1 (Miller 1997). The program has not been updated since 1996.

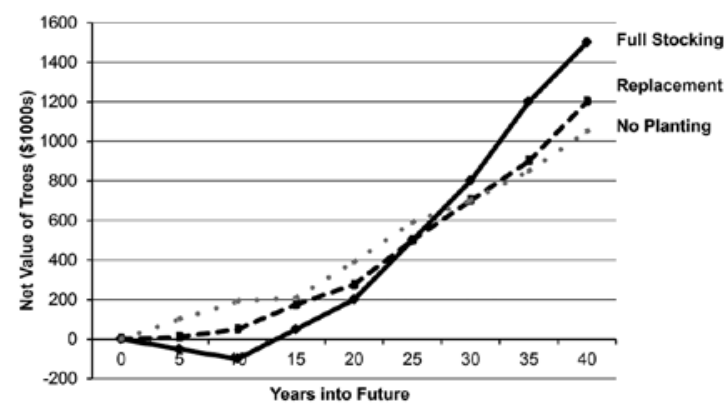

Figure 7. 


\section{Economics of removal decisions}

Two recent studies examine the economics of tree removal. Scott and Betters (2000) presented a method for evaluating on an economic basis whether to remove and replace a tree, or retain and maintain a tree. The authors advocated use of the individual tree appraisal methods (replacement) developed by the Council of Tree and Landscape Appraisers (CTLA) to calculate the replacement value of a single tree as a type of capital asset, taking into account species, location, and condition. To extrapolate the benefits of a replacement tree (i.e., the value of a future tree), the authors used a discount rate of $2.5 \%$ per year. In considering only whether to remove a tree (regardless of replacement), they proposed calculating the present net value of the existing tree as the difference between benefits now and benefits in the future, less the discounted stream of periodic maintenance costs incurred over the time period between the present and the time at which the tree would be removed. In determining whether to remove and replace the tree, these authors added to the present net value of the existing tree the discounted "land expectation value," or the value of a replacement tree with a given life expectancy assuming replacement recurs into the infinite future. Scott and Betters (2000) presented an example of applying their methods to a single elm tree (Ulmus americana) on the Colorado State University campus. Present net value of retaining the existing elm and engaging in maintenance (annual treatment) for a period of eight years was USD \$95 (\$70 in 2000\$) (Scott and Betters 2000). Replacing the existing tree immediately yielded present net benefits of $\$ 92$ (\$68 in 2000\$), while retaining and maintaining the tree for eight years and then removing and replacing yields benefits of $\$ 413$ (\$305 in 2000\$) (Scott and Betters 2000). Thus, for this example, the greatest benefit was to retain and treat the elm tree for eight years and then replace the tree with a Dutch elm disease- (DED) resistant elm (Scott and Betters 2000). In this example, the "cost" of removal and replacement was the lost stream of benefits resulting from premature removal of the tree.

Tinus and LaMana (2013) reframed tree removal costs by quantifying the economics of harvesting urban trees and recovering, as lumber and other wood products, the wood waste that would otherwise have been disposed of in a landfill. Tinus and LaMana (2013) compared the value of recovered forest products and avoided landfill disposal costs to standard tree removal and disposal costs. They found an average avoided disposal cost per job site of USD $\$ 877$, compared to an average hauling cost of $\$ 842$, yielding only a marginal difference of $\$ 35$ to landowners (excluding additional milling costs and the value of secondary products (Tinus and LaMana 2013). However, this analysis omitted the costs of hauling wood to a disposal site, although the cost of hauling wood to a milling site was included.

In addition to the studies cited here, several others have examined the economic costs of tree removal and replacement decisions in the context of diseased trees or those threatened by pests or disease (see section "Pest and disease management" for a more complete discussion of pest costs).

\section{Non-economic costs of removal}

A non-economic (i.e., non-monetizable) cost of tree removal may be impacts on the remaining trees in the landscape. An interesting study by Kane (2008) examined the impact of recent maintenance activities at a campsite, including pruning and removal of other trees, on the likelihood of the failure of trees at that site. He found that removal of other trees at a campsite increased the likelihood of root-related tree failures due to increased root exposure and increased exposure to winds and decreased crown contact with neighboring trees (Kane 2008). While this study did not explicitly examine costs, it can be inferred that an additional cost of tree removal, at a site where trees are in close proximity, increased risk of failure for the remaining trees at that site.

Unlike the tree pruning in which pruning cycles can be increased (time between pruning events lengthened) during periods of budget crisis, the removal of dead and high-risk trees should never be deferred unless property damage and personal injury can be avoided by closure of areas with high-risk trees (e.g., closing a park area to avoid human contact). Of course, there are often costs to these alternative actions as well. If tree removal is deferred and alternate precautionary steps are not taken, the costs can include injury liability and damages paid in court settlements (see section "Tree risk management"). 


\section{Infrastructure repair}

Infrastructure repair costs occur when trees interfere with other parts of the built environment in a way that damages the infrastructure, necessitating its repair. Infrastructure damaged by trees most commonly includes curb and sidewalks (or other concrete surfaces, such as roads or parking lots), but also can include sewer lines and gutters. Common repair activities for damage associated with trees includes removing and replacing concrete and root pruning. A survey of 15 cities conducted between 1992 and 1994 by McPherson and Peper (1995) indicated that total concrete and sewer repair costs, for damage attributed to trees, was on average USD $\$ 7.11$ per street tree annually ( $\$ 4.28$ in $1992 \$$ ), or $25 \%$ of annual total tree program expenses. Sidewalk and curb repair costs averaged $\$ 5.63$ per tree ( $\$ 3.39$ in $1992 \$)$, while sewer repair costs averaged $\$ 2.76$ per tree (\$1.66 in 1992\$) (McPherson and Peper 1995). Many cities may require the local property owner to cover the cost of these repairs. In a related later study, McPherson (2000) estimated that approximately $\$ 95.6$ million ( $\$ 70.7$ million in $2000 \$$ ) is spent annually in the state of California to repair damage resulting from conflicts between tree root systems and infrastructure.

Hauer et al. (1993) found infrastructure repair activities near street trees led to $5.7 \%$ reduction in tree condition and a $4.1 \%$ increased mortality. This resulted in a nearly USD $\$ 800,000$ annual loss in urban forest value. A program to reduce the effects of construction on street trees was developed and this reduced the impacts of construction on tree health and survival with no greater mortality and only $2.6 \%$ difference in tree condition (Koeser et al. 2013).

Infrastructure repair itself is a cost of improper tree location or species selection (i.e., neither the "right tree" nor the "right place"; Wagar and Barker 1983). However, not repairing infrastructure damaged by trees can yield worse damage; Randrup et al. (2001) noted that tree roots reportedly cause more than $50 \%$ of all sewer blockages. In the case of total sewer collapse, repair costs can eclipse the costs of new construction, where the cost of proper root pruning and removal is only one-sixth of total replacement (Randrup et al. 2001).

\section{Pest and disease management}

The clear management goal of maintenance practices related to pest and disease managementnamely, control of the pest or disease-has yielded well-documented economics of pest/disease management. Additionally, there is a clear counterfactual case for many types of pests/diseases; if lack of pest management actions results in pest infestation and eventually tree mortality, the cost of management actions can be directly compared to the value of trees lost (e.g., VanNatta et al. 2012).

\section{The beginnings of pest economics: Dutch elm disease}

Several models exist to examine the costs and benefits of different pest management scenarios. The economics of controlling Dutch elm disease (Ophiostoma novo-ulmi) was examined by many authors between the 1960s to mid-1980s. An early example of a paper on the economics of pest management is a 1976 U.S. Forest Service report on the economics of Dutch elm disease control (Cannon and Worley 1976). Cannon and Worley (1976) observed tree sanitation approaches to project tree mortality rates for "Best," "Fair," and "Poor" pest control scenarios. They found removing diseased elms promptly through sanitation was the most cost-effective approach. Intensive sanitation (three annual inspections) was $25 \%$ less costly than conventional sanitation (one annual inspection) with prevention of tree mortality and associated tree removal costs. Himelick and Ceplacha (1976) reported the costs of treating trees infected with DED by pruning compared to the costs of removal and replacement: when less than $5 \%$ of the crown is showing DED symptoms, USD \$1,216 (\$297 in $1976 \$$ ) can be saved by pruning $(\$ 233 ; \$ 57$ per tree in $1976 \$$ ) instead of removing $(\$ 1,499 ; \$ 354$ in $1976 \$)$ DED-infected trees. Kostichka and Cannon (1981) analyzed the costs of DED management for cities in Wisconsin, U.S., and attributed $79 \%$ of all costs to tree removal and disposal, $14 \%$ of costs to treatment (11\% to fungicide injection and $3 \%$ to root-graft barriers), and 7\% to inspection activities. Sherwood and Betters (1981) performed a benefit-cost analysis of DED control scenarios with the goal of determining which scenario yields the highest return on investment (highest benefit-cost ratio). They found that an "intensive consistent sanitation" manage- 
ment scenario consisting of two inspections per year, prompt removal of infected trees, and deadwood pruning of all trees yielded the highest benefit-cost ratio of the examined alternatives (Sherwood and Betters 1981). These authors also provided a stepby-step method for assessing the benefits and costs of alternative DED management programs for a municipality considering undertaking DED control (Sherwood and Betters 1981). Other authors over the years have examined the biological costs (e.g., mortality of trees, development of fungicide-resistant DED strains) of DED control and treatment efforts without matching economic data to treatment options (Wilson 1976; Campana 1977; Gregory and Allison 1979; Sherald and Gregory 1980).

\section{Economics of other pests}

Studies examining the economics of pest management include Dreistadt and Dehlsten (1986; costs of aphid honeydew pest management), Jetter et al. (1997; costs of ash whitefly biological control), Kovacs et al. [2010; economic damage potential of the emerald ash borer (EAB), Agrilus planipennis], and VanNatta et al. (2012; cost of EAB management). Dreistadt and Dahlsten (1986) described a study undertaken to determine the costs of aphid honeydew pest management for tuliptrees (Liriodendron tulipifera) compared to removal and replacement of diseased trees. Costs of pest management were estimated as direct costs by city arborists and parks supervisors and included structural and clearance trimming, removal and replacement of $1 \%$ of trees each year, and sidewalk repair and modifications necessitated by tuliptree trunk growth (Dreistadt and Dahlsten 1986). Removal and replacement of 400 tuliptrees with London planetrees (Platanus acerifolia) was only $63 \%$ of the cost of continued maintenance of the tuilptrees (USD $\$ 223,000$ compared to $\$ 354,000$ in $1984 \$$; Dreistadt and Dahlsten 1986). Costs excluded from this analysis include potential liability costs, temporarily lost aesthetic value, and other tree benefits.

Jetter etal. (1997) performed a benefit-cost analysis of the use of a parasitic wasp (Encarsia inaron) to biologically control the ash whitefly (Siphoninus phillyreae), which attacks ash (Fraxinus spp.) and ornamental pear (Pyrus spp.) trees. They compared the change in appraised value due to pest damage (benefits) to the costs incurred by the entities conducting the biological control (including personnel, travel expenses, and materials; Jetter et al. 1997). Given total program costs of only USD $\$ 2.0$ million ( $\$ 1.2$ million in $1992 \$$ ), total net benefits of the program were almost $\$ 536$ million wholesale ( $\$ 323$ million in $1992 \$$ ) and $\$ 682$ million retail (\$411 million in 1992\$) for street trees only (Jetter et al. 1997). In other words, if biological control efforts had not occurred, over a half billion dollars in street tree appraisal value would have been lost.

\section{Current pest threat: Emerald ash borer}

Kovacs et al. (2010) examined the costs that will be incurred for municipalities as a result of emerald ash borer damage in municipalities in a 25-state region centered on Detroit, Michigan, U.S. (the epicenter of North America's EAB infestation), between 2009 and 2019. Using simulations of the spread of $\mathrm{EAB}$ and costs of various treatment options or removal and replacement for trees of different sizes, the authors estimated the costs of EAB management (Kovacs et al. 2010). The analysis assumed that homeowners and tree managers act optimally and "[maximize] the present value of a stream of benefits and costs associated with each tree by choosing among four actions-1) do nothing, 2) remove, 3) remove and replace, or 4) treat with an insecticide that prevents injury from EAB" (Kovacs et al. 2010, p. 573). They concluded that EAB will cost U.S. communities an estimated $\$ 11.4$ billion ( $\$ 10.7$ billion in $2010 \$$ ) in discounted terms between 2009 and 2019 (Kovacs et al. 2010). Note that the Kovacs et al. (2010) scenario was an optimal one, assuming completely rational actors acting optimally in the face of EAB infestation, and does not allow for calculation of the costs of doing nothing.

VanNatta et al. (2012) provided more detailed $\mathrm{EAB}$ management scenarios based on the projected management costs and tree value. They simulated the costs of four management scenarios for the ash tree population on the University of WisconsinStevens Point campus: 1) doing nothingand removing ash trees as they die; 2 ) immediately removing all ash trees over a five-year period; 3) immediately removing and replacing ash trees with non-ash trees; and 4) minimizing mortality by treating all ash trees with approved insecticide treatments (VanNatta et al. 2012). The costs of doing nothing to combat EAB (scenario 1) yielded an annual 
present value of benefits nearly equal to the costs of removing ash trees as they die (benefit-cost ratio of 1.02). However, the net value of remaining trees after a 20-year period in the do-nothing scenario ranged from USD $\$ 868$ (using i-Tree Streets to value the benefits of trees) to $\$ 44,913$ (using CTLA appraisal methods to assess tree values; VanNatta et al. 2012). This was compared to the best-case scenario (based on CTLA appraisal values) of treating all trees (scenario 4; yielding $\$ 84,610$ net value remaining after 20 years; VanNatta et al. 2012).

The economic analyses of EAB detailed here have yielded tools available for managers facing decisions about managing EAB. These tools include the EAB Calculator (Sadof et al. 2011; Purdue 2015) and the EAB PLANning Simulator (VanNatta et al. 2012; UWSP 2015), both of which allow urban forest managers to calculate costs of different control methods for emerald ash borer.

\section{Integrated pest management}

Integrated pest management (IPM) and monitoring of pest and disease populations rose in prominence for urban areas in the late-1970s as a means of reducing the risk of economically damaging pest outbreaks in urban areas and the costs of controlling outbreaks. IPM methods are not unique to urban forestry and arboriculture but originated in the field of agriculture to monitor and manage crop pests. In 1978, Olkowski and Olkowski introduced the idea of an urban IPM to arborists as a means of more effectively dealing with the diversity of vegetation pests found in cities and to enable costeffective dissemination of practices to homeowners. These authors introduced the concept of injury level, or the level of pest infestation (in number of insects per unit of vegetation; e.g., leaf area) at which damage to the tree is unacceptable and treatment of the pest becomes desirable (Olkowski and Olkowski 1978). Establishing injury levels for urban pests and trees helps minimize application of pesticides (i.e., costs of pesticide use) and make effective use of limited resources for treating pests in the urban forest (Olkowski and Olkowski 1978). Ball and Marsan (1991) advocated for the establishment of an action threshold, as the level of pest infestation or incidence just below the injury level at which economic or aesthetic thresholds are reached, and at which treatment should begin. In economic terms, the economic injury level occurs at the point at which the marginal benefits obtained when trees are treated for a pest (i.e., the increased benefits due to prolonged tree lifespan) equal the marginal costs of the treatment (i.e., the dollars and time spent treating trees). An aesthetic action threshold is a management approach with treatment meant to avoid surpassing an unacceptable injury level, which is a point that vitality is reduced detrimentally. Subsequent authors have encouraged proactive monitoring (including visual inspection of trees for damage and pest incidence, locating vulnerable populations of trees, trapping and baiting of pests, and monitoring of environmental conditions suitable for specific pests or for pest outbreaks; Raupp 1985; Ball 1987), preventative maintenance (to promote tree health; Nielsen 1986), and minimizing periods of tree stress to reduce susceptibility to pest or disease infestation (Moorman 1985). Reardon et al. (1987) provided a description of implementing an IPM program to control gypsy moth infestation (although results of the program are not provided). However, beyond statements asserting that IPM and monitoring practices are economical, no authors advocating IPM provide explicit information about its costs or compare costs to traditional management of pest populations with pesticides.

\section{Maintenance Not Commonly Quantified in Municipal Budgets}

Some types of tree maintenance are much less completely quantified and studied. The costs associated with risk management, watering, mulching, soil and nutrient management, staking, tree support systems (e.g., cabling, bracing, and propping), and protection during construction are less explicit in literature from the field of arboriculture and urban forestry. These tend to be tasks that do not earn line items in city budgets, and so do not appear as clearly quantified in records. These types of maintenance may occur less systematically across a population of trees in the urban forest, and may be more likely borne by a nonprofit organization, neighborhood, or citizen in charge of tree care.

\section{Tree risk management}

One of these less-studied costs of not maintaining trees is related to tree risk and liability management. If a lack of maintenance results in a tree that fails 
and injures person or property, damages may be awarded to the injured party, payable by the individual liable for the tree (Ryan 1985; Anderson and Eaton 1986; Merullo and Valentine 1992). Systematic inspection of trees for tree risks and documenting inspection efforts can help minimize the potential for liability suits that may happen due to tree-related damage, injury, or casualty (Anderson and Eaton 1986; Sharon 1987; Sreetheran et al. 2011). The risks of harm posed by an assessed tree can be compared to the costs and benefits of removal or other risk-mitigating actions (Ryan 1985; Stewart et al. 2013). Additionally, preemptively adopting practices to promote urban tree and forest health-including best management planting practices and regular maintenance, maintaining a mixture of age classes and species, and promptly removing declining trees-can also help minimize potential costs incurred due to tree failure (Anderson and Eaton 1986). Several authors have discussed proper management of individual mature trees at risk of decline (Shigo 1975; Shigo 1982; Clark and Matheny 1991), or groups of mature trees in forest settings (Bakken 1995). Yamamoto (1985) argued that programmed tree maintenance (whereby tree pruning is performed for a certain geography within the city every year) is defensible in negligence and liability claims of personal injury or property damage caused by street trees. Insuring against these risks can also help minimize liability-related tree costs (Carpenter 1987). Storm events are one particular source of concern in assessing risk in the urban forest; although a few authors surveyed damage caused to urban trees by storms (Gibbs and Greig 1990; Gibbs and Palmer 1994; Escobedo et al. 2009; Hauer et al. 2011). Escobedo et al. (2009) and Hauer et al. (2011) provided cost estimates for debris clean-up from storm damage. An understanding is needed on how and if early maintenance leads to a costs savings from tree damage resulting from storms.

\section{Watering}

Watering and irrigation of trees accounted for approximately $4.0 \%$ of municipal tree expenses (Kielbaso 1990). Watering is widely acknowledged to be crucial to planted tree establishment and survival. The biological costs of not watering are clear: trees that receive inadequate water exhibit decreased con- dition, and if moisture levels are low for a sufficiently lengthyperiod of time the treemay even die (Kozlowski and Pallardy 1997). Many authors have examined the importance of watering for urban trees (e.g., Pellet et el. 1980; Kramer 1987; Costello et al. 2005; Costello 2013; Symes and Connellan 2013); however, few have examined the economics of watering.

\section{Costs of not watering}

If watering leads to greater tree survival, there is a clear cost to not watering. If the cost is less than the benefit, then the net benefit value added resulting from irrigation could then be calculated as the lifetime benefits produced by the additional trees that survive as a result of irrigation. For instance, if irrigation results in 15 of 20 planted trees surviving over the 10 of 20 trees that survive without irrigation, the lifetime benefits of these five additional trees is the value added by irrigation. The net benefit of irrigation is the total added benefits less the cost of irrigation. Conversely, if forgoing irrigation results in a loss of five trees that otherwise would have survived, the costs of not irrigating are equal to the benefits forgone less the avoided costs of irrigation. Gilman (2001) authored one of the few studies that collected data that enables measurement of the costs of not watering trees in terms of cost per live, established tree (see sidebar The Costs of Not Watering). Outside of this study, to the knowledge of the authors, there are no other complete studies on the economic costs of not watering trees.

\section{Mulching}

Mulching is a type of tree maintenance frequently employed at the time of planting. Mulching decreases tree root competition with turf grass (Samyn and de Vos 2002), weeds or other vegetation (Watson 1988; Green and Watson 1989), can improve soil moisture content (Watson 1988), and may protect a tree from damage by lawnmowers or weed trimmers. Mulching improves the health of a tree, increasing both above- and belowground growth, and trees mulched during establishment may require less maintenance later in life (Green and Watson 1989). However, few articles have empirically demonstrated the long-term benefits of mulching trees. Most studies have been conducted during the course of a single (e.g., Gilman and Grabosky 2004) or few 


\section{The Costs of Not Watering}

Gilman (2001) examined the impacts of watering throughout the first six months (the whole summer) after transplanting, compared to only watering for five weeks (no summer irrigation). For four of six packaging and transplanting treatments, higher mortality rates of trees not irrigated following transplanting led to a greater cost due to replacing dead trees and thus a higher cost per-live tree (Table 1, based on data from Gilman 2001). In only one case (root pruned ball-and-burlap trees) was there not a financial advantage of water. However, in all cases the watered trees grew more. Unfortunately, the research conducted by Gilman (2001) was one of the few papers to provide data that afford calculation of the cost per live tree of maintenance practices related to establishment.

Table 2. Cost savings (in 2013\$) resulting from watering during establishment for six different planting packaging types. (Based on data presented by Gilman 2001. Original costs in Gilman (2001), from which these values were calculated, were assumed to be published in 2000\$.) All currency is in USD\$.

\begin{tabular}{|c|c|c|c|c|}
\hline \multirow[t]{2}{*}{ Treatment } & \multicolumn{2}{|c|}{ Cost per live tree } & \multirow[b]{2}{*}{$\begin{array}{l}\text { Savings } \\
\text { (per tree) }\end{array}$} & \multirow[b]{2}{*}{$\begin{array}{l}\text { Percen } \\
\text { savings }\end{array}$} \\
\hline & $\begin{array}{l}\text { Summer } \\
\text { irrigation }\end{array}$ & $\begin{array}{l}\text { No summer } \\
\text { irrigation }\end{array}$ & & \\
\hline Plastic container with SpinOut & $\$ 602$ & $\$ 1,061$ & $\$ 459$ & 76.2 \\
\hline Air root-pruning (ARP) & $\$ 602$ & $\$ 909$ & $\$ 307$ & 51.0 \\
\hline Low-profile ARP container & $\$ 602$ & $\$ 1,591$ & $\$ 989$ & 164.3 \\
\hline Root-pruned, field-grown B\&B & $\$ 518$ & $\$ 371$ & $-\$ 147$ & -28.4 \\
\hline Non-root-pruned, field-grown B\&B & $\$ 518$ & $\$ 518$ & $\$ 0.00$ & 0.0 \\
\hline
\end{tabular}

growing seasons (e.g., Green and Watson 1989). Furthermore, no studies have reported on the costs of mulching. Municipal budgets almost never include mulching as a specific line item.

\section{Soil and nutrient management}

Soils in urban environments may lack adequate nutrients for trees to grow (Scharenbroch and Catania 2012). Fertilizing trees-either at the time of planting or later in their life-can help correct damage or poor conditions resulting from improper nutrient management (both deficiencies and excesses; e.g., Himelick and Himelick 1980; Smith 1988). Fertilization to correct deficiencies and promote growth could also theoretically increase the number of established trees in the urban forest to a rate at which they reach an "environmentally functional size" and provide benefits (Harris et al. 2008 , p. 195). If nutrient management would lead to survival or improved condition of the trees managed, the benefits forgone due to lack of nutrients that support reaching these objectives are the "costs" of this decision. Examples to illustrate this have been documented by examining tree decline.

One particular type of nutrient managementnitrogen fertilization-has been examined by a few studies. Nitrogen fertilization in general promotes tree growth (Scharenbroch and Lloyd 2004). In an early example, Neely (1984) conducted a controlled experiment that found that application of nitrogen fertilizer (both in isolation or in combination with glyphosate herbicide) increased tree growth rate of black walnut (Juglans nigra), sycamore (Platanus occidentalis), Norway maple, and honeylocust, relative to untreated control trees. However, Harris et al. (2008) compiled five studies that tested the effects of several nitrogen fertilization rates on 10 tree species in both field- and container-growth settings, and found no impact of nitrogen fertilization on tree growth or establishment. Gilman (2004) tested six types of soil backfill amendments but also found no benefits to growth or survival of any of these treatments during the first four monthsafter transplanting.

\section{Early maple decline studies}

Maple decline and methods of treatment was studied by several authors in the late 1970s and early 1980s. Maple decline was assumed to be a result of multiple stress factors, such as manganese deficiency (Smith and Mitchell 1977; Funk and Peterson 1980) or excessive exposure to road salts (Rich and Walton 1979; Funk and Peterson 1980). Ru- 
bens (1978) outlined four direct costs of maple decline: "1) periodic deadwood removal, 2) eventual removal cost, 3) replanting or replacement cost, and 4) loss in value of the mature tree" (p. 33). Rubens (1978) declared that, "The cost of soil desalination on a continuous basis to protect healthy sugar maples (Acer saccharum) not affected by other environmental or man-made stresses is less than the costs attributable to nonprovision of this maintenance" (p. 41), although specific costs were not determined empirically. Other authors have noted additional methods of mitigating maple decline without providing dollar figures, including application of manganese compounds directly to the trunk or foliage (Smith and Mitchell 1977), and soil injection or dry application of manganese sulfate monohydrate (Funk and Peterson 1980); applications of nitrogen were ineffective (Rich and Walton 1979).

\section{Fixing chlorosis}

Himelick and Himelick (1980) analyzed methods of ameliorating chlorosis in several species via iron treatments, noting that excessive application of calcium or phosphorous in turf fertilizers or too much soil moisture could contribute to chlorosis. These authors observed that injecting the tree with ferric citrate or ferric ammonium citrate is a "reasonably effective and economical" method of treating chlorosis in pin oak (Quercus palustris) and sweetgum trees (Liquidambar styraciflua) (Himelick and Himelick 1980), although again no costs figures were provided. Smith (1988) also discussed methods for ameliorating nutrient-deficiencyrelated leaf chlorosis, but did not link chlorosis to tree performance, benefits, or other maintenance needs outside of the chlorosis treatment itself.

\section{Costs of not managing soils or nutrients}

None of the aforementioned studies provided empirical estimates of the costs of nutrient treatments. Additionally, few studies have quantified the impacts of nutrient treatments on tree structure (e.g., survival or growth), function, or benefits. Studies that did provide estimates of the impact of treatments on tree survival (Gilman 2004; Rich and Walton 1979) and growth (Harris et al. 2008) found no effect of fertilization, or a small impact on root growth (Percival et al. 2004).

\section{Tree support systems}

Several tree support systems, including staking, cabling, bracing, and propping serve the purpose of supporting a tree and improving strength during periods of vulnerability. Staking serves to support small or recently planted trees or trees in windy areas (Smiley and Lily 2006). Bracing, cabling, and propping serve as methods of supporting weakened, old, or severely damaged trees that would otherwise fail, thereby prolonging their useful life. Relatively few studies have discussed the economic benefits of staking trees. Black (1978) discussed staking young trees as a means of reducing vandalism. Bracing and cabling as methods of supporting mature trees were discussed by Mayne (1975) and others, but the current literature review yielded no articles on the economics-benefits or costs-of cabling and bracing.

\section{Protection during construction}

Protecting trees during construction is a means of preserving many of the benefits provided by trees that otherwise might be damaged or removed during construction of a building or road. Protection activities theoretically have costs. Koeser et al. (2013) found that trees near road construction activities were twice as likely to succumb to mortality as trees not adjacent to road construction. Tree protection during building construction can include establishing a barrier between the tree and construction activities, creating "disturbance-free zones" around wooded areas to limit root disturbance, and grading construction areas to guide potentially contaminated construction runoff away from root zones (Anderson and Barrows-Broaddus 1989). Tree protection during road construction or utility installation can include tunneling and boring with an aim to avoid root damage (Yingling et al. 1979; Jim 2003). Tree protection and preservation during construction is a specialized field composed of consulting arborists and contractors who rarely publish, and thus few studies explicitly examining the economics of tree protection exist.

\section{Economics of tree protection}

The loss of forest benefits due to inadequate protection of existing trees or forests from damage during construction or other activities results in a number of types of costs: costs to the final homeowner, who might otherwise benefit from 
preserved trees, costs to the contractor or developer who pays to remove trees, and, where preserved trees would have increased final sale price, lost revenue for the developer or homebuilder (Anderson and Barrows-Broaddus 1989). Additional costs not mentioned in the tree protection literature include: decreased home equity, loss of additional tax revenues that would have accrued due to increased property values of lots with mature trees, and costs to homeowners to remove trees not sufficiently protected. A survey of residential homebuilders in Amherst, Massachusetts, and Athens, Georgia, U.S., revealed that the costs of removing trees on a heavily wooded lot during development averaged USD $\$ 3,844$ ( $\$ 1,000$ in $1977 \$$ ) in Amherst but only $\$ 707$ (\$250 in 1980\$) in Athens (Siela and Anderson 1982). Costs of preserving trees on lots averaged $\$ 6,535$ ( $\$ 1700$ in $1977 \$)$ in Amherst and only $\$ 792$ ( $\$ 280$ in $1980 \$$ ) in Athens (Seila and Anderson 1982). The authors reported that in both Amherst and Athens, builders recovered the higher cost of preservation in an increased final home price (Seila and Anderson 1982), although real estate data were not provided.

Tree protection efforts can also take the form of establishing boundaries around wooded areas near residential yards to protect them from substantial human intrusion in the form of yard extension, waste disposal, forest clearing activities, or more (McWilliam et al. 2010). McWilliam et al. (2010) estimated that approximately $20 \%-50 \%$ of the first $20 \mathrm{~m}$ of the edges of municipal forests in Ontario, Canada, were disturbed due to human encroachment. Although encroachment could yield a significant loss in benefits provided by these forests, McWilliam et al. (2010) did not provide data about magnitude of lost benefits, nor the costs of enforcement that could curb encroachment activities.

\section{Other types of care and maintenance}

The costs of other types of tree care are even less certain than the types of maintenance costs previously examined: nursery management (Tate 1984a); use of growth control chemicals (Carvell 1975; Olenick 1977; Domir 1978; Domir and Roberts 1983; Holewinski and Johnson 1983); topping (Carvell 1978; Karlovich et al. 2000); root pruning (Gilman 1990; Achinelli et al. 1997); applying herbicides to control weeds (Smith 1975); general grass and turf management (Dawson et al. 2001); tree site (Berrang et al. 1985) or species (Miller and Miller 1991) selection; wrapping trees (intended to prevent frost crack, Hart and Dennis 1978; Hvass 1985); compaction and other soil remediation efforts (Day et al. 1995); managing woodlots or patches of forest in urban areas (e.g., Tyrvainen et al. 2003); and inventorying or monitoring trees to determine maintenance needs (e.g., Tate 1985; Sreetheran et al. 2011). This literature review did not find literature on the costs of not performing these types of maintenance.

\section{Tree Appraisal and Valuation}

Tree appraisal and valuation efforts are not a type of maintenance per se (although the de facto monitoring of trees that occurs during on-site appraisal is certainly connected to tree maintenance efforts in the most holistic of tree management situations). However, tree appraisal and valuation is intimately connected to assessing the costs of maintenance and the value lost or benefits forgone due to inadequate maintenance of trees.

If a lack of adequate maintenance results in the complete loss of the tree, appraisal value is one measure of the cost of not maintaining the tree. Many authors have examined tree appraisal and valuation, or methods of attributing value to a landscape tree. Methods include expert appraisal value (e.g., Mayne 1978; Chadwick 1980; Watson 2002; Ponce-Donoso et al. 2009), replacement cost (cost of replacing the tree with one of similar size and species, e.g., Felix 1978; Mayne 1978), amenity value (property value change due to addition or removal of the tree, e.g., Mayne 1978; Morales et al. 1983; Tyrvainen 1997; Ishikawa and Fukushige 2012), current value (value of the benefits produced annually, e.g., Brown and Boogaerdt 2006), stated preference approach (willingness-to-pay for a preserved tree, e.g., Notaro and De Salvo 2010), and various accounting methods (that take into account discounting streams of benefits to their present value, e.g., McPherson 1992; Brown and Boogaerdt 2006; Peterson and Straka 2011), among other methods. Different methods of appraisal can attribute dramatically different values to the same trees (Watson 2002; Price 2003; Ponce-Donoso et al. 2009), and all methods have at least some limitations (Price 2003). 


\section{Incorporation of maintenance into tree appraisal}

Most common methods of appraisal do not take into account the explicit value of maintained compared to unmaintained trees, or the direct value of maintenance performed on trees, although Felix (1978) mentioned that a lack of maintenance can affect appraisal value. Condition and location-factors that may be correlated with past maintenance activities or current maintenance needs-are frequently included in appraisal values (Davis 1983).

A few appraisal methods include maintenance costs. For example, the Standard Tree Evaluation Method used in New Zealand includes estimation of maintenance costs at $14 \%$ of the retail tree and planting costs (Watson 2002). The CTLA Guide for Plant Appraisal Cost-of-Cure Method also includes long-term maintenance costs. The capital gains method also includes maintenance costs; this method combines the cost of planting a replacement tree, the interest accrued on capital investments equivalent to the price of the tree during the time period in which it takes the replacement to grow to the size of the original tree, and the costs of maintenance over this time period into a more accurate assessment of the value of a tree (Mayne 1978). Ponce-Donoso et al. (2009) reviewed seven methods used by individual Chilean municipalities. They found three methods that explicitly incorporate the value of annual maintenance performed on the tree, quantified as average municipal maintenance cost per tree for all trees maintained in a given year (although the authors note that this places a higher value on trees maintained by inefficient or more expensive maintenance practices; Ponce-Donoso et al. 2009). Notaro and De Salvo (2010) conducted a contingent valuation analysis to uncover people's willingness to pay for efforts to preserve and protect cypress (Cupressus sempervirens L.) trees from a threatening disease in the landscape of northern Italy. They discovered that together, people would be willing to pay between EUR €122-€141 million over a 100-year tree life span (discounted to present value at 2\%) for research and treatment efforts; unfortunately, the article presumed "economic viability of caring for the cypresses in order to maintain the current landscape" (Notaro and
De Salvo 2010, p. 80), but did not present actual costs of disease control that could be compared to the willingness-to-pay values to determine the costs of not controlling the cypress canker.

\section{GAPS IN THE LITERATURE}

As the literature reviewed here demonstrates, studies explicitly examining the costs of not maintaining trees and the urban forest are scarce. A few authors discuss the impacts of foregoing maintenance entirely: McPherson (2001) quantified the "benefits forgone" due to not planting trees to sufficiently shade parking lots in compliance with ordinance in Sacramento, California, U.S. Ryder and Moore (2013) compared the costs of formative pruning on recently planted trees to the much greater costs of structural pruning on mature trees that had not been formatively pruned (see sidebar The Costs of Not Pruning). Studies from utility arboriculture examined the costs of insufficiently maintained utility rightsof-way as manifested in lost billable customer service hours and the extra time and money required to restore service, including time spent on reactive or corrective tree maintenance. Using data from Gilman (2001), researchers can infer the costs of not watering newly-planted trees based on high mortality rates for non-irrigated trees (see sidebar The Costs of Not Watering).

What the urban forestry and arboriculture literature lack are studies that allow researchers and practitioners to infer the effects of different levels of maintenance. In other words, what are the costs of maintaining trees just a little less than optimally? What about a lot less than optimally? For instance, what are the costs incurred by watering newly-planted trees only once per month rather than once a week during the first growing season after transplanting? For cashstrapped municipalities, nonprofits, or companies with limited resources to care for trees, knowing the impacts of ratcheting up or winding down maintenance activities from current levels is important to efficient allocation of public funds.

\section{Levels of Maintenance}

It is often not the difference between maintenance and no maintenance that urban foresters 
are interested in, but the difference between more maintenance and less maintenance. In this vein, future experimental research should track the impacts of different levels of maintenance or maintenance regimes (Table 3 ). Borrowing language ecologists use to talk about disturbance (e.g., Walker and Willig 1999), the level of urban forest maintenance can be described as occurring at a particular intensity (how much), frequency (how often), duration (for how long), and extent (what part of a tree or which trees). Who performs the maintenance (e.g., an adjacent homeowner, municipal forestry crews, contractor) and what type of maintenance they perform (e.g., watering, pruning) also matters. The combination of the types of maintenance activities performed with any given frequency, intensity, and duration across a particular area of the urban forest (extent) can be called a maintenance regime. For example, city forestry crews will water the trees on 3rd Street with $56.78 \mathrm{~L}$ of water each week that it does not rain at least $2.54 \mathrm{~cm}$, for three summers after transplanting. It would be helpful to be able to compare the economic costs (e.g., dollar expenditure) of different maintenance regimes with the tree outcomes (e.g., structure, function) and benefits produced. This would allow urban forest managers to determine ideal maintenance regimes, given the available budget resources and desired goals (e.g., benefits). [Note that this concept of maintenance regime is similar to the "maintenance intensity" idea used by Escobedo et al. (2011).]

\section{Long-Term Data on Maintenance}

A final piece of information that is lacking in the current literature is long-term data about the impacts of levels of maintenance on tree longevity or lifetime-benefits produced. Although municipal or other tree inventories commonly include maintenance recommendations of some sort, these inventories are rarely updated to capture performed maintenance activities or the costs of these activities. Incorporating procedures for capturing costs into repeated inventories would help provide long-term data on maintenance regimes and their impact on tree populations.

\section{CONCLUSION}

A wealth of approaches and studies document the benefits of urban trees, forests, and greenspaces; research on costs has yet to catch up. Several take home messages emerged through this literature review. First, the costs of maintaining trees are clearer than are the costs of not maintaining trees in the urban forest. Municipal budget expenditures are the primary source of dollar figures used in benefitcost analyses of tree populations, and so the monetary costs of maintenance commonly tracked by municipalities (planting, pruning, removal, pest management, and sometimes infrastructure repair) are fairly well understood. It is rare to find figures reported in the literature for types of maintenance not featured as line items in municipal budgets.

Second, the costs of not maintaining trees does not only equate to deferring maintenance to a later date; rather, urban forest managers at the municipal level must often make the decision (or non-decision) to not care for trees, and there can be a resultant cost much later in a tree's life span that was not anticipated. These costs are then left for the next generation of urban foresters and city residents to deal with.

Table 3. Key elements of an urban forest maintenance regime.

\begin{tabular}{|c|c|c|}
\hline Element & Explanation & Examples \\
\hline Type & The particular maintenance activity & Prune, mulch, stake, etc. \\
\hline Who & $\begin{array}{l}\text { Party physically performing } \\
\text { maintenance activity }\end{array}$ & $\begin{array}{l}\text { City tree crews, contracted certified arborist, } \\
\text { nonprofit, adjacent homeowner, etc. }\end{array}$ \\
\hline Intensity & How much & $20 \%$ of the crown, $18.9 \mathrm{~L}$ or $57.8 \mathrm{~L}$ of water, etc. \\
\hline Frequency & How often & A four- or six-year pruning cycle, once per week, etc. \\
\hline Duration & How long & $\begin{array}{l}\text { For just the first growing season after transplanting, } \\
\text { throughout a tree's life, etc. }\end{array}$ \\
\hline Extent & What part of a tree or which trees & $\begin{array}{l}\text { Branches below } 4.3 \mathrm{~m} \text { clearance level, all trees in a city, trees on } \\
\text { heavily traveled road corridors, trees in a downtown area, etc. }\end{array}$ \\
\hline
\end{tabular}


Third, some particular maintenance non-actions stand above the rest: 1) not caring for trees in early establishment (i.e., not watering; see sidebar The Costs of Not Watering); 2) not managing for diseases or pests, such as $\mathrm{DED}$ or $\mathrm{EAB}$, and the subsequent loss of net benefits; 3 ) not maintaining the urban forest as a whole by not planting trees (and, again, the loss of net benefits resulting therefrom; see sidebar The Costs of Not Planting); and 4) instances where lack of tree care may result in decline in tree condition and/ or future liability issues. Of these, points two and three are most clearly addressed in the literature.

Fourth, partnerships between researchers and those who plant and care for trees-municipalities, consulting arborists, nonprofits, utility arborists, and more-could expand the information available for examining the costs of maintaining and not maintaining trees (e.g., The Costs of Not Maintaining Trees summit, March 2015, which involved both researchers and practitioners). Future research partnerships should aim to examine the influence of maintenance regimes on costs and tree outcomes, including examining how the frequency, intensity, duration, and extent of different types of tree maintenance activities are connected to the structure, function, and benefits of trees. Large, long-term data sets, with lots of variables, are one way to begin to understand more fully the marginal causal impact of different levels and combinations of maintenance activities on tree and urban forests outcomes, benefits, and costs.

Additional research priorities under the banner of "the costs of not maintaining trees" could include questions, such as comparing maintenance priorities for practitioners of municipal, utility, and commercial arboriculture; the difference between optimal maintenance (i.e., maintenance that maximizes net tree benefits) and adequate maintenance (i.e., the minimally sufficient amount of maintenance necessary to secure tree survival for a desired length of time, or to provide a desired minimum amount of benefits); and the need of different tree species for different levels of maintenance. Consensus on specific research priorities will be identified in an upcoming paper emerging from the ISA Costs of Not Maintaining Trees research symposium and summit held in March 2015 (both inclusive of researchers and practitioners from within the fields of arboriculture and urban forestry, including municipal and utility foresters, consulting arborists, forest economists, and social-ecological systems and governance scholars). One outcome of the summit is a planned retrospective study to examine tree growth and longevity, and to model if and how tree maintenance may explain tree growth and longevity. Another prospective study to develop an international network of sites for long-term urban forest monitoring and tracking of maintenance of trees at these sites is being recommended.

Acknowledgments. This manuscript was supported by a contract from the International Society of Arboriculture Science and Research Committee. Author Jess Vogt performed this work as part of her doctoral research at the School of Public and Environmental Affairs at Indiana University, Bloomington.

\section{LITERATURE CITED}

Achinelli, F.G., J.L. Marquina, and R.M. Marlats. 1997. Exploratory study of the relationships between tree growth, site conditions, and maintenance practices in street plantings of Fraxinus pennsylvanica Marshall of La Plata City, Argentina. Arboricultural Journal 21:305-315.

Anderson, L.M., and J. Barrows-Broaddus. 1989. Inexpensive ways to improve homebuilders tree survival. Journal of Arboriculture 15(1):13-16.

Anderson, L.M., and T.A. Eaton. 1986. Liability for damage caused by hazardous trees. Journal of Arboriculture 12(8):189-195.

Bai, S., W. Chaney, and Y. Qi. 2004. Response of cambial and shoot growth in trees treated with paclobutrazol. Journal of Arboriculture 30(3):137-145.

Baker, F.A., and D.W. French. 1985. Economic effectiveness of operational therapeutic pruning for control of Dutch elm disease. Journal of Arboriculture 11(8):247-249.

Bakken, S.R. 1995. Group-tree hazard analysis. Journal of Arboriculture 21(3):150-155.

Ball, J. 1987. Efficient monitoring for an urban IPM. Journal of Arboriculture 13(7):174-177.

Ball, J., and P. Marsan. 1991. Establishing monitoring routines and action thresholds for a landscape IPM service. Journal of Arboriculture 17(4):88-93.

Berrang, P., D.F. Karnosky, and B.J. Stanton. 1985. Environmental factors affecting tree health in New York City. Journal of Arboriculture 11(6):185-189.

Black, M.E. (1978). Tree vandalism: Some solutions. Journal of Arboriculture 4(5):114-116.

BLS. 2015. Consumer Price Index Inflation Calculator-Bureau of Labor Statistics. <www.bls.gov/data/inflation_calculator.htm>

BOC. 2015. Inflation Calculator-Bank of Canada. <www.bankofcanada.ca/rates/related/inflation-calculator>

Brown, A.M., and M.A.H. Boogaerdt. 2006. Accounting for suburban tree information systems. Corporate Social Responsibility and Environmental Management 13(5):275-285.

Browning, D.M., and H.V. Wiant. 1997. The economic impacts of deferring electric utility tree maintenance. Journal of Arboriculture 23(3):106-112. 
Campana, R.J. 1977. Limitations of chemical injection to control Dutch elm disease. Journal of Arboriculture 3(7):127-129.

Cannon, W.N., and D.P. Worley. 1976. Dutch elm disease control: Performance and costs. USDA Forest Service Research Paper No. NE-345. USDA Forest Service Northeastern Forest Experiment Station. 8 pp.

Carpenter, H.A. 1987. Risk management and bookkeeping systems. Journal of Arboriculture 13(3):81-85.

Carvell, K.L. 1975. Environmental impact of herbicides on electric transmission line rights-of-way. Journal of Arboriculture 2(7):129-130.

Carvell, K.L. 1978. Response of forest-grown trees to topping. Journal of Arboriculture 4(12):275-284.

Chadwick, L.C. 1980. Review of guide for establishing values of trees and other plants. Journal of Arboriculture 6(2):48-50.

Chaney, W.R. 2005. Growth retardants: a promising tool for managing urban trees. Purdue University Extension Bulletin FNR-252-W

Chapman, D.J. 1981. Tree species selection with an eye towards maintenance. Journal of Arboriculture 7(12):313-316.

Churack, P.L., R.W. Miller, K. Ottman, and C. Koval. 1994. Relationship between street tree diameter growth and projected pruning and waste wood management costs. Journal of Arboriculture 20(4):231-236.

Clark, J.R. and N. Matheny. 1991. Management of mature trees. Journal of Arboriculture 17(7):173-184.

Clark, J.R., and N. Matheny. 2010. The research foundation to tree pruning: A review of the literature. Arboriculture \& Urban Forestry 36(3):110-120.

Costello, L. 2013. Urban trees and water: An overview of studies on irrigation needs in the Western United States and a discussion regarding future research. Arboriculture \& Urban Forestry 39(3):132-135.

Costello, L.R., K.S. Jones, and D.D. McCreary. 2005. Irrigation effects on the growth of newly planted oaks (Quercus spp.). Journal of Arboriculture 31(2):83-88.

David, T.F. 1979. The Long Island Lighting Company productivity incentive program for tree trimming. Journal of Arboriculture $5(2): 42-44$

Davis, S.H. 1983. Tree valuation pitfalls. Journal of Arboriculture 9(6):164-166.

Dawson, L.A., E.I. Duff, C.D. Campbell, and D.J. Hirst. 2001. Depth distribution of cherry (Prunus avium L.) tree roots as influenced by grass root competition. Plant and Soil 231:11-19.

Day, S., N. Bassuk, and H. van Es. 1995. Effects of four compaction remediation methods for landscape trees on soil aeration, mechanical impedance and tree establishment. Journal of Environmental Horticulture 13:64-71.

Diller, O.D. 1975. Funding city tree planting and maintenance. Journal of Arboriculture 1(10):196-198.

Domir, S.C. 1978. Chemical control of tree height. Journal of Arboriculture 4(7):145-153.

Domir, S.C., and B.R. Roberts. 1983. Tree growth retardation by injection of chemicals. Journal of Arboriculture 9(8):217-224.

Donovan, G.H., and D. Butry. 2009. The value of shade: Estimating the effect of urban trees on summertime electricity use. Energy and Buildings 41(6):662-668.
Dreistadt, S.H., and D.L. Dahlsten. 1986. Replacing a problem prone street tree saves money: A case study of the tuliptree in Berkeley, California. Journal of Arboriculture 12(6):146-149.

Duchchere, K. 1999. Just six bids for St. Paul city work. Star Tribune. Minneapolis, MN Dec. 24. p. B5.

Dykes, A.M. 1980. Right-of-way management program. Journal of Arboriculture 6(3):74-76.

Escobedo, F., C. Luley, J. Bond, C. Staudhammer, and C. Bartel. 2009. A hurricane debris and damage assessment for Florida urban forests. Arboriculture \& Urban Forestry 35:100-106.

Escobedo, F.J., T. Kroeger, and J.E. Wagner. 2011. Urban forests and pollution mitigation: Analyzing ecosystem services and disservices. Environmental Pollution 159: 2077-2087.

Evans, P.S., and J.E. Klett. 1985. The effects of dormant branch thinning on total leaf, shoot, and root production from bareroot Prunus cerasifera 'Newportii.' Journal of Arboriculture 11(5):149-151.

Felix, R. 1978. Tree appraisal. Journal of Arboriculture 4(9):195-197.

Funk, R., and W. Peterson. 1980. Nutrient treatments for sugar maple decline. Journal of Arboriculture 6(5):124-129.

FXTOP. 2015. Euro Inflation Calculator-FXTOP. <http://fxtop. com/en/inflation-calculator.php>

Gibbs, J.N., and B.J.W. Greig. 1990. Survey of parkland trees after the Great Storm of October 16, 1987. Arboriculture Journal 14:321-347.

Gibbs, J.N., and C.A. Palmer 1994. A survey of damage to roadside trees in London caused by the application of de-icing salt during the 1990/91 winter. Arboriculture Journal 18:321-343.

Gilman, E.F. 1990. Tree root growth and development. II. Response to culture, management and planting. Journal of Environmental Horticulture 8(4):220-227.

Gilman, E.F. 2001. Effect of nursery production method, irrigation, and inoculation with mycorrhizae-forming fungi on establishment of Quercus virginiana. Journal of Arboriculture 27(1):30-39.

Gilman, E.F. 2004. Effects of amendments, soil additives, and irrigation on tree survival and growth. Journal of Arboriculture 30(5):301-310.

Gilman, E.F., and J. Grabosky. 2004. Mulch and planting depth affect live oak (Quercus virginiana Mill.) establishment. Journal of Arboriculture 30(5):311-317.

Goodfellow, J.W., and A. Kayihan. 2013. Development of a business case for scheduling utility vegetation management on a preventative vs. corrective maintenance basis. TREE Fund Grant \#12UARF-01, Phases I and II Final Report.

Green, T.L., and G.W. Watson. 1989. Effects of turfgrass and mulch on the establishment and growth of bare-root sugar maples. Journal of Arboriculture 15(11):268-272.

Gregory, G.F., and J.R. Allison. 1979. The comparative effectiveness of pruning versus pruning plus injection of trunk and/or limb for therapy of Dutch elm disease in American elms. Journal of Arboriculture 5(1):1-3.

Guikema, S.D., R.A. Davidson, and H. Liu. 2006. Statistical models of the effects of tree trimming on power system outages. IEEE Transactions on Power Delivery 21(3):1549-1557.

Harris, J.R., S.D. Day, and B. Kane. 2008. Nitrogen fertilization during planting and establishment of the urban forest: A collection of five studies. Urban Forestry \& Urban Greening 7:195-206. 
Harris, R.W. 1985. TLC may be dangerous to your trees. Journal of Arboriculture 11(3):73-75.

Hart, J.H., and G.K. Dennis. 1978. Effect of tree wrap on the incidence of frost crack in Norway maple. Journal of Arboriculture 4(10):226-227.

Hauer, R.J., A.J. Hauer, D.R. Hartel, and J.R. Johnson. 2011. Rapid assessment of tree debris following urban forest ice storms. Arboriculture \& Urban Forestry 37(5):236-246.

Hauer, R.J., R.W. Miller, and D.M. Ouimet. 1994. Street tree decline and construction damage. Journal of Arboriculture 20(2):94-97.

Hauer R.J., J.M. Vogt, and B.C. Fischer. 2015. What is the cost of not maintaining the urban forest? Arborist News 24(1):12-19.

Henning, R.E. 1990. Work measurement and productivity improvement. Journal of Arboriculture 17(3):80-81.

Hensley, D.L. 1979. Pruning: Why, when, and how. Journal of Arboriculture 5(10):239-240.

Himelick, E.B., D.W. Cepiecha. 1976. Dutch elm disease eradication by pruning. Journal of Arboriculture 2(5):81-84.

Himelick, E.B., and K.J. Himelick. 1980. Systematic treatment for chlorotic trees. Journal of Arboriculture 6(7):192-196.

Holewinski, D.E., and P.A. Johnston. 1983. Cost comparison of right-of-way treatment methods. Journal of Arboriculture 9(6):153-155.

Hvass, N. 1985. Defending street trees against road salt in Denmark. Journal of Arboriculture 11(2):61-64.

Ishikawa, N., and M. Fukushige. 2012. Effects of street landscape planting and urban public parks on dwelling environment evaluation in Japan. Urban Forestry \& Urban Greening 11:390-395.

Jetter, K., K. Klonsky, and C.H. Pickett. 1997. A cost/benefit analysis of the ash whitefly biological control program in California. Journal of Arboriculture 23(2):65-72.

Jim, C.Y. 2003. Protection of urban trees from trenching damage in compact city environments. Cities 20(2):87-94.

Jo, H.-K. 2002. Impacts of urban greenspace on offsetting carbon emissions for middle Korea. Journal of Environmental Management 64:115-126.

Jo, H.-K., and E.G. McPherson. 1995. Carbon Storage and Flux in Urban Residential Greenspace. Journal of Environmental Management 45:109-133.

Johnstone, R.A. 1988. Economics of utility lateral trimming. Journal of Arboriculture 14(3):74-77.

Kane, B. 2008. Tree failure following a windstorm in Brewster, Massachusetts, USA. Urban Forestry \& Urban Greening 7(1):15-23.

Karlovich, D.A., J.W. Groninger, and D.D. Close. 2000. Tree condition associated with topping in southern Illinois communities. Journal of Arboriculture 26(2):87-91.

Kendall, A., and E.G. McPherson. 2012. A life cycle greenhouse gas inventory of a tree production system. International Journal of Life Cycle Assessment 17:444-452.

Kennedy, R.W. 1990. Contracting municipal tree maintenance. Journal of Arboriculture 16(11):300-303.

Kenney, W.A., and C. Idziak. 2000. The state of Canada's municipal forests-1996 to 1998. Forestry Chronicle 76(2):231-234.

Kielbaso, J. 1990. Trends and issues in city forests. Journal of Arboriculture 16(3):69-76.

Kielbaso, J., G. Haston, and D. Pawl. 1982. Municipal tree management in the U.S.-1980. Journal of Arboriculture 8(10):253-257.
Klonowski, A.D. 1991. Collecting data on contractor performance. Journal of Arboriculture 17(4):105-106.

Koeser, A., R. Hauer, K. Norris, and R. Krouse. 2013. Factors influencing long-term street tree survival in Milwaukee, WI, USA. Urban Forestry \& Urban Greening 12(4):562-568.

Kostichka, C.J., and W.N. Cannon. 1981. Costs of Dutch elm disease management in Wisconsin communities. Journal of Arboriculture 10(9):250-254.

Kovacs, K.F., R.G. Haight, D.G. McCullough, R.J. Mercader, N.W. Siegert, and A.M. Liebhold. 2010. Cost of potential emerald ash borer damage in U.S. communities, 2009-2019. Ecological Economics 69(3):569-578.

Kozlowski, T.T., and S.G. Pallardy. 1997. Growth Control in Woody Plants. Academic Press, San Diego, California, U.S. 641 pp.

Kramer, P. 1987. The role of water stress in tree growth. Journal of Arboriculture 13(2):33-38.

Krause R.M., S.K. Mincey, and J.M. Vogt. 2010. Tying Local Policy, Management, and Institutional Arrangements to Environmental Outcomes: The Role of Urban Forests in Municipal Sustainability Initiatives. Association for the Advancement of Public Policy and Management 2010 Conference, November 4-6, 2010, Boston, Massachusetts, U.S.

Kuntz, P.A., R.D. Christie, and S.S. Venkata. 2002. Optimal vegetation maintenance scheduling of overhead electric power distribution systems. IEEE Transactions on Power Delivery 17(4):1164-1169.

Leal, L., D. Biondi, and R. Rochadelli. 2008. Custos de implantação e manutenção da arborização de ruas da cidade de Curitiba, PR. The implementation and maintenance costs of urban street trees in Curitiba, PR. Revista Árvore 32(3):557-565. (English abstract only.)

Lough, W.B. 1991. Contracting for urban tree maintenance. Journal of Arboriculture 17(1):16-17.

Loukaitou-Sideris, A. 2011. Sidewalks: Conflict and negotiation over public space. MIT Press, Boston, Massachusetts, U.S. 344 pp.

Luley, C.J., S. Sisinni, and A. Pleninger. 2002. The effect of pruning on service requests, branch failures, and priority maintenance in the city of Rochester, New York, U.S. Journal of Arboriculture 28(3):137-143.

Maco, S.E., and E.G. McPherson. 2003. A practical approach to assessing structure, function, and value of street tree populations in small communities. Journal of Arboriculture 29(2):84-97.

Mayne, L.S. 1978. Tree and landscape evaluation. Journal of Arboriculture 4(1):19-22.

McHale, M.R., E.G. McPherson, and I.C. Burke. 2007. The potential of urban tree plantings to be cost effective in carbon credit markets. Urban Forestry \& Urban Greening 6(1):49-60.

McPherson, E.G. 1992. Accounting for benefits and costs of urban greenspace. Landscape \& Urban Planning 22:41-51.

McPherson, E.G. 2000. Expenditures associated with conflicts between street tree root growth and hardscape in California, United States. Journal of Arboriculture 26(6):289-297.

McPherson, E.G. 2001. Sacramento's parking lot shading ordinance: environmental and economic costs of compliance. Landscape \& Urban Planning 57:105-123.

McPherson, E.G. 2003. A benefit-cost analysis of ten street tree species in Modesto, California, U.S. Journal of Arboriculture 29(1):1-9. 
McPherson, E.G., D. Nowak, G. Heisler, S. Grimmond, C. Souch, R. Grant, and R. Rowntree. 1997. Quantifying urban forest structure, function, and value: The Chicago Urban Forest Climate Project. Urban Ecosystems 1:49-61.

McPherson, E.G., and P.J. Peper. 1995. Infrastructure repair costs associated with street trees in 15 cities. pp. 49-64. In: G. Watson and D. Neely (Eds.). Proceedings of the International Workshop on Trees and Buildings, Trees and Building Sites. International Society of Arboriculture, Savoy, Illinois, U.S.

McPherson, E.G., J.R. Simpson, P.J. Peper, and Q. Xiao. 1999. Benefitcost analysis of Modesto's municipal urban forest. Journal of Arboriculture 25(5):235-248.

McPherson, E.G., J.R. Simpson, P.J. Peper, S.E. Maco, and Q. Xiao. 2005. Municipal forest benefits and costs in five U.S. cities. Journal of Forestry 103(8):411-416.

McPherson, E.G., J.R. Simpson, P.J. Peper, S.L. Gardner, K.E. Vargas, S.E. Maco, and Q. Xiao. 2006. Midwest Community Tree Guide: Benefits, Costs, and Strategic Planting. General Technical Report No. PSW-GTR-199. United States Department of Agriculture Forest Service Pacific Southwest Research Station, Davis, California, U.S. 98 pp.

McWilliam, W., P. Eagles, M. Seasons, and R. Brown. 2010. Assessing the degradation effects of local residents on urban forests in Ontario, Canada. Arboriculture \& Urban Forestry 36(6):253-260.

Medicky, E.J. 1976. Right-of-way development and maintenance. Journal of Arboriculture 2(3):53-58.

Merullo, V.D., and M. J. Valentine. 1993. Arboriculture and the Law. International Society of Arboriculture, Champaign, Illinois, U.S. $110 \mathrm{pp}$

Miller, K.C., and R.E. Abbott. Results of TGR Survey. Journal of Arboriculture 17(2):44-48.

Miller, R.H., and R.W. Miller. 1991. Planting survival of selected street tree taxa. Journal of Arboriculture 17(7):185-191.

Miller, R.W, R.J. Hauer, and L.P. Werner. 2015. Urban Forestry: Planning and Managing Urban Greenspaces, third edition. Waveland Press, Long Grove, Illinois, U.S. 560 pp.

Miller, R.W., and M.S. Morano. 1984. URFOR/SIMULATION: An Urban forest management computer simulation/game. Journal of Arboriculture 10(2):55-63.

Miller, R.W., and W.A. Sylvester. 1981. An economic evaluation of the pruning cycle. Journal of Arboriculture 7(4):109-112.

Millward, A.A., and S. Sabir. 2010. Structure of a forested urban park: Implications for strategic management. Journal of Environmental Management 91(11):2215-2224.

Moorman, G.W. 1985. Scheduling woody ornamental plant disease management. Journal of Arboriculture 11(1):22-24.

Morales, D.J., F.R. Micha, and R.L. Weber. 1983. Two methods of valuating trees on residential sites. Journal of Arboriculture 9(1):21-24.

Neely, D. 1984. Grass competition for nitrogen around landscape trees. Journal of Environmental Horticulture 2(3):86-88.

Nielsen, D.G. 1986. Planning and implementing a tree health care practice. Journal of Arboriculture 12(11):265-268.

Notaro, S., and M. De Salvo. 2010. Estimating the economic benefits of the landscape function of ornamental trees in a sub-Mediterranean area. Urban Forestry \& Urban Greening 9(2):71-81.

Nowak, D.J. 1990. Street tree pruning and removal needs. Journal of Arboriculture 16(12):309-315.
Nowak, D.J., J.C. Stevens, S.M. Sisinni, and C.J. Luley. 2002. Effects of urban tree management and species selection on atmospheric carbon dioxide. Journal of Arboriculture 28(3):113-122.

O’Brien, P.R., and K.A. Joehlin. 1992. Use of municipal tree maintenance standards. Journal of Arboriculture 18(5):273-277.

O’Brien, P.R., K.A. Joehlin, and D.J. O'Brien. 1992. Performance standards for municipal tree maintenance. Journal of Arboriculture 18(6):307-315.

O’Bryan, C.M., T.J., Straka, S.R. Templeton, and J.D. Caldwell. 2007. Economic patterns in U.S. arboriculture. Arboriculture \& Urban Forestry 33(4):292-299.

Olenik, C.J. 1977. The wonderful power of selectivity to power line rights-of-way. Journal of Arboriculture 3(9):173-176.

Olkowski, H., and W. Olkowski. 1978. Urban integrated pest management. Journal of Arboriculture 4(11):241-246.

Overbeek, J.A. 1979. Increased efficiency in urban forestry. Journal of Arboriculture 5(11):262-264.

Pauleit, S., N. Jones, G. Garcia-Martin, J.L. Garcia-Valdecantos, L.M. Riviere, L. Vidal-Beaudet, M. Bodson, and T.B. Randrup. 2002. Tree establishment practices in towns and cities - Results from a European survey. Urban Forestry \& Urban Greening 1:83-96.

Pellett, H., R. Hummel, and L. Mainquist.1980. Relationship of fall watering practice to winter injury of conifers. Journal of Arboriculture 6(6):146-149.

Peper, P.P., E.G. McPherson, J.R. Simpson, K.E. Vargas, and Q. Xiao. 2009. Lower Midwest Community Tree Guide: Benefits, Costs, and Strategic Planning. General Technical Report No. PSW-GTR-219. United States Department of Agriculture Forest Service Pacific Southwest Research Station, Davis, California, U.S. 127 pp.

Percival, G.C., G.A. Fraser, and S. Barnes. 2004. Soil injections of carbohydrates improve fine root growth of established urban trees. Arboricultural Journal 28:95-101.

Perry, P.B. 1977. Management's view of the tree trimming budget. Journal of Arboriculture 3(8):157-160.

Peterson, K.S., and T.J. Straka. 2011. Specialized discounted cash flow analysis formulas for valuation of benefits and costs of urban trees and forests. Arboriculture \& Urban Forestry 37(5):200-206.

Pierce, P.A. 1980. Urban forestry productivity. Journal of Arboriculture 6(10):279-280.

Ponce-Donoso, M., L. Moya, and O. Bustos-Letelier. 2009. Evaluation of formulas for the appraisal of urban trees in municipalities of Chile. Scientia Forestalis, Piracicaba 37(83):321-329.

Price, C. 2003. Quantifying the aesthetic benefits of urban forestry. Urban Forestry \& Urban Greening 1(3):123-133.

Purdue. 2015. Emerald Ash Borer Cost Calculator-Purdue University Extension. <http://extension.entm.purdue.edu/treecomputer>

Randrup, T.B., E.G. McPherson, and L.R. Costello. 2001. Tree root intrusion in sewer systems: Review of extent and costs. Journal of Infrastructure Systems 7(1):26-31.

Raupp, M.J. 1985. Monitoring: An essential factor to managing pests of landscape trees and shrubs. Journal of Arboriculture 11(12):349-355.

Reardon, R., M. McManus, D. Kolodny-Hirsch, R., Tichenor, M. Raupp, C. Schwalbe, R. Webb, and P. Meckley. 1987. Development and implementation of a gypsy moth integrated pest management program. Journal of Arboriculture 13(9):209-216. 
Rich, S., and G.S. Walton. 1979. Decline of curbside sugar maples in Connecticut. Journal of Arboriculture 5(12):265-268.

Roy, S., J. Byrne, and C. Pickering. 2012. A systematic quantitative review of urban tree benefits, costs, and assessment methods across cities in different climatic zones. Urban Forestry \& Urban Greening 11(4):351-363.

Rubens, J.M. 1978. Soil desalination to counteract maple decline. Journal of Arboriculture 4(2):33-42.

Ryan, H.D.P. 1985. Vegetation's impact on urban infrastructure. Journal of Arboriculture 11(4):112-115.

Ryder, C.M., and G.M. Moore. 2013. The arboricultural and economic benefits of formative pruning street trees. Arboriculture \& Urban Forestry 39(1):17-24.

Sadof, C., L. Purcell, F. J. Bishop, C. Quesada, and Z. Zhang. 2011. Evaluating restoration capacity and costs of managing the emerald ash borer with a web-based cost calculator in urban forests. Arboriculture \& Urban Forestry 37(2):74-83.

Samyn, J., and B. de Vos. 2002. The assessment of mulch sheets to inhibit competitive vegetation in tree plantations in urban and natural environment. Urban Forestry \& Urban Greening 1:25-37.

Scharenbroch, B.C., and M. Catania. 2012. Soil quality attributes as indicators of urban tree performance. Arboriculture \& Urban Forestry 38:214-228.

Scharenbroch, B.C., and J.E. Lloyd. 2004. A literature review of nitrogen availability indices for use in urban landscapes. Journal of Arboriculture 30:214-230.

Schwarz, C.F., and J.A. Wagar. 1987. Street tree maintenance: How much should spend now to save later? Journal of Arboriculture 13(11):257-261.

Scott, J.L., and D.R. Betters. 2000. Economic analysis of urban tree replacement decisions. Journal of Arboriculture 26(2):69-77.

Seila, A.F., and L.M. Anderson. 1982. Estimating costs of tree preservation on residential lots. Journal of Arboriculture 8(7):182-185.

Sharon, E.M. 1987. Tree health management: Evaluating tree for hazard. Journal of Arboriculture 13(12):285-293.

Sherald, J.L., and G.F. Gregory. 1980. Dutch elm disease therapy. Journal of Arboriculture 6(11):287-290.

Sherwood, S.C., and D.R. Betters. 1981. Benefit-cost analysis of municipal Dutch elm disease control programs in Colorado. Journal of Arboriculture 7(11):291-298.

Shigo, A.L. 1975. Some new ideas in tree care. Journal of Arboriculture 1(12):234-237.

Shigo, A.L. 1982. Tree decay in our urban forests: What can be done about it. Plant Disease 66(9):763-768.

Sievert, R.C. Jr. 1988. Public awareness and urban forestry in Ohio. Journal of Arboriculture 14(2):48-51.

Sisinni, S.M., W.C. Zipperer, and A.G. Pleninger. 1995. Impacts from a major ice storm: Street tree damage in Rochester, NY. Journal of Arboriculture 21(3):156-167.

Smiley, E.T., and S. Lilly. 2006. Best Management Practices: Tree Support Systems: Cabling, Bracing, Guying, and Propping. International Society of Arboriculture, Champaign, Illinois, U.S. 35 pp.

Smith, E.M. 1975. Tree stress from salts and herbicides. Journal of Arboriculture 1(11):201-205.

Smith, E.M. 1988. An overview of systemic nutrient treatments in trees. Journal of Arboriculture 14(10):240-242.

Smith, E.M., and C.D. Mitchell. 1977. Manganese deficiency of red maple. Journal of Arboriculture 3(5):87-88.
Sreetheran, M., M. Adnan, and A.K. Khairil Azuar. 2011. Street tree inventory and tree risk assessment of selected major roads in Kuala Lumpur, Malaysia. Arboriculture \& Urban Forestry 37(5):226-235.

Stewart, M.G., D.O. Callaghan, and M. Hartley. 2013. Review of QTRA and risk-based cost-benefit assessment of tree management. Arboriculture \& Urban Forestry 39(4):165-172.

Strohbach, M.W., E. Arnold, and D. Haase. 2012. The carbon footprint of urban green space-A life cycle approach. Landscape \& Urban Planning 104:220-229.

Symes, P., and G. Connellan. 2013. Water management strategies for urban trees in dry environments: Lessons for the future. Arboriculture \& Urban Forestry 39(3):116-124.

Tate, R.L. 1984a. Municipal tree management in New Jersey. Journal of Arboriculture 10(8):229-233.

Tate, R.L. 1984b. Status and operating costs of selected, municipallyowned tree nurseries in the northeast United States. Journal of Arboriculture 10(10):286-288

Tate, R.L. 1985. Uses of street tree inventory data. Journal of Arboriculture 11(7):210-213.

Tate, R.L. 1986. Contracting for city tree maintenance needs. Journal of Arboriculture 12(4):97-100.

Tate, R.L. 1987. A guide to contracting for municipal tree maintenance services. Journal of Arboriculture 13(1):18-20.

Tate, R.L. 1993. How to compete for budget dollars by privatizing the tree care operation. Journal of Arboriculture 19(1):44-47.

Thompson, R., N. Pillsbury, and R. Hanna. 1994. The Elements of Sustainability in Urban Forestry. Urban Forest Ecosystems Institute, California Polytechnic State University, San Luis Obispo, California, U.S. 61 pp.

Tinus, C.A., and M. LaMana. 2013. Conversion efficiency and economics of urban wood utilization. Arboriculture \& Urban Forestry 39(1):25-30.

Tschantz, B.A., and P.L. Sacamano. 1994. Municipal tree management in the United States. Davey Research Group and Communication Research Associates, Inc. Report, Kent, Ohio, U.S. 58 pp.

Tyrvainen, L. 1997. The amenity value of the urban forest: an application of the hedonic pricing method. Landscape and Urban Planning 37:211-222.

Tyrväinen, L., H. Silvennoinen, and O. Kolehmainen. 2003. Ecological and aesthetic values in urban forest management. Urban Forestry \& Urban Greening 1(3):135-149.

Ulrich, E. 1983. Correlating tree disturbances, tree work, and tree budgets. Journal of Arboriculture 9(3):79-84.

UWSP. 2015. Emerald Ash Borer PLANning Simulator Version Beta. University of Wisconsin-Stevens Point. <http://cnrfiles. uwsp.edu/hauer/EAB-PLANSVersionBeta.xlsx $>$

VanNatta, A.R., R.H. Hauer, and N.M. Schuettpelz. 2012. Economic analysis of emerald ash borer (Coleoptera: Buprestidae) management options. Journal of Economic Entomology 105(1):196-206.

Vogt, J.M., S.K. Mincey, B.C. Fischer, and M. Patterson. 2014 Planted Tree Re-Inventory Protocol, Version 1.1. Bloomington Urban Forestry Research Group at the Center for the Study of Institutions, Population and Environmental Change, Indiana University, Bloomington, Indiana, U.S. Accessed 28 April 2014. $<$ www.indiana.edu/ cipec/research/bufrg_protocol $>$

Wagar, J.A., and P.A. Barker. 1983. Tree root damage to sidewalks and curbs. Journal of Arboriculture 9(7):177-181. 
Wagner, J.F. 1970. Time study of tree trimming. pp 97-101. In: Proceedings of the 46th International Shade Tree Conference.

Walker, L.R., and M.R. Willig. 1999. An Introduction to Terrestrial Disturbances. pp. 1-16. In: L.R. Walker (Ed.). Ecosystems of Disturbed Ground (Ecosystems of the World 16). Elsevier, New York, New York, U.S.

Watson, G. 1988. Organic mulch and grass competition influence tree root development. Journal of Arboriculture 14(8):200-203.

Watson, G. 2002. Comparing formula methods of tree appraisal. Journal of Arboriculture 28(1):11-18.

Wilson, C.L. 1976. Recent advances and setbacks in Dutch elm disease research. Journal of Arboriculture 2(7):136-139.

Yamamoto, S.T. 1985. Programmed tree pruning and public liability. Journal of Arboriculture 11(1):15-17.

Yingling, E.L., C.A. Keeley, S. Little, and J. Burtis. 1979. Reducing damage to shade and woodland trees from construction activities. Journal of Arboriculture 5(5):97-105.

Zillmer, R.E., J.L. Boeder, and K.G. Genich. 2000. A productivity system for tree climbing training. Journal of Arboriculture 26(2):97-105.

Jess Vogt, MPA, MSES, Ph.D. (corresponding author)

Department of Environmental Science and Studies

College of Science and Health

DePaul University

1110 West Belden Avenue

Chicago, Illinois 60614, U.S.

jessica.m.vogt@gmail.com

Richard J. Hauer, Ph.D., C.F.

College of Natural Resources

University of Wisconsin Stevens Point

2100 Main Street

Stevens Point, Wisconsin 54481, U.S.

Burnell C. Fischer, Ph.D., C.F.

School of Public and Environmental Affairs, and

The Vincent and Elinor Ostrom Workshop in Political Theory and Policy Analysis

Indiana University Bloomington

513 North Park Avenue

Bloomington, Indiana 47408, U.S. 


\section{APPENDIX. LIST OF ATTRIBUTES AND VALUES USED IN CODING LITERATURE.}

\begin{tabular}{|c|c|}
\hline ATTRIBUTE & EXPLANATION (Values) \\
\hline Citation key & $\begin{array}{l}\text { Unique article identifier for referencing the article in the text of the literature review, composed of the last name of the } \\
\text { author(s), "et al." if more than } 2 \text { authors, the four-digit year of publication, and a, b, c, etc., if more than one article was } \\
\text { published by that author in that year. }\end{array}$ \\
\hline Authors & Full list of all authors in the format: Last, First; Last, First;... (for authors with initials only: Last, F M) \\
\hline Date & Year of publication \\
\hline Title & Full title of the article, including subtitle if applicable \\
\hline Keywords & List of publication-assigned keywords \\
\hline Publication & Full name of the journal or publication in which the article was published \\
\hline Volume & Volume number of publication \\
\hline Issue & Issue number of publication \\
\hline Pages & Page numbers in publication in which article appears \\
\hline Discipline & $\begin{array}{l}\text { What discipline is the article from? Arboriculture/UF (articles from within the field of urban forestry) [name of discipline] } \\
\text { (for articles from outside the field) }\end{array}$ \\
\hline $\begin{array}{l}\text { Review, Original, or } \\
\text { Opinion }\end{array}$ & $\begin{array}{l}\text { Is the article a Review of available literature, or an Original research study presenting original data, or an Opinion (personal } \\
\text { experience) piece? }\end{array}$ \\
\hline City of research & Location of study performed: City, State, Country, or N/A \\
\hline Research Question & Brief statement of the article's research question, problem, or objective \\
\hline Type of cost or benefit & $\begin{array}{l}\text { Type of cost or benefit incurred due to maintenance or management activities (or lack thereof): Economic (labor, capital, } \\
\text { dollars, etc.), Not Economic (e.g., social, community social capital, cultural, human health \& well-being, ecological or } \\
\text { environmental, other non-economic costs) }\end{array}$ \\
\hline $\begin{array}{l}\text { Type of cost or benefit } \\
\text { - describe }\end{array}$ & More detailed text description of the type of cost or benefit analyzed, e.g., Ecological, Economic (utilitarian), etc. \\
\hline Outcome variable(s) & Dependent variable(s) used in analysis \\
\hline Type of care & $\begin{array}{l}\text { Type of care or maintenance activity being undertaken or not undertaken: Planting, Pruning, Mulching, Watering, Removing, } \\
\text { Appraisal, Pest/Disease Management, etc. }\end{array}$ \\
\hline Care details & Details of the type of care examined in the article, or the types of care considered in analyses of costs of care \\
\hline Independent variable(s) & List of specific independent variable(s) used in analysis, including any control variables. \\
\hline Stage of life of trees & Stage of life of trees studied: Recently planted, Young, Semi-mature, Mature, Senescent, or All \\
\hline $\begin{array}{l}\text { Empirical versus } \\
\text { Subjective }\end{array}$ & $\begin{array}{l}\text { Method of cost or benefit assessment is Empirical (uses real data of some sort, including reviews that summarize results } \\
\text { of data collected by others) or Subjective (includes a more qualitative assessment of costs and benefits, without any actual } \\
\text { data). Cannot be N/A-studies either make use of data, or they do not. }\end{array}$ \\
\hline Type of economic analysis & $\begin{array}{l}\text { For economic studies only: Direct cost measurement, Hedonic pricing (econometrics), Willingness-to-pay, Contingent } \\
\text { valuation (contingent choice), Appraisal value, Historical cost method, Current value, Net market value, Replacement cost, } \\
\text { Deprival value, Other social survey, Cost-benefit analysis, Cost efficiency analysis, Cost effectiveness analysis, Qualitative (for } \\
\text { all studies that use some sort of non-monetary qualitative method of assessment), N/A (for studies that do not use a type of } \\
\text { cost assessment method) }\end{array}$ \\
\hline Framework & Brief, general description of the valuation or framework as it might be useful to assessing the costs of not maintaining trees \\
\hline Results & General notes on the results of the study \\
\hline Language & Language the article is written in \\
\hline Links & $\begin{array}{l}\text { Links to online sources (e.g., a supplementary online materials or online appendix; direct link to the article text if available } \\
\text { online, etc.) }\end{array}$ \\
\hline Other Notes & Any other notes on the article \\
\hline $\begin{array}{l}\text { Inferred or calculated } \\
\text { "Cost"? }\end{array}$ & Are the costs "calculated" in any way (direct or otherwise), or can they merely be "inferred" from the article? \\
\hline Full Citation & Citation in APA style based on bibliographic information \\
\hline Abstract & Full text of the abstract \\
\hline Anno Bib Blurb & A brief paragraph explaining how the article is useful to the literature review. \\
\hline References cited? & Number of sources listed in literature cited \\
\hline
\end{tabular}


Résumé. La littérature actuelle concernant les forêts urbaines est abondante en ce qui a trait aux données quantitatives et qualificatives des bénéfices et des soins octroyés aux arbres, mais plus rare sur les conséquences résultant d'un sous-investissement dans les arbres. Cet article présente les résultats d'une revue de littérature sur les "coûts du non-entretien des arbres» ordonnée par l' ISA Science and Research Committee (comité sur la science et la recherche de l'ISA). Les auteurs ont résumé la recherche documentaire au domaine de l'arboriculture et de la foresterie urbaine en cherchant des réponses aux questions suivantes: quels sont les coûts d'entretien des arbres et de la forêt urbaine? quels sont les coûts du non-entretien de ces arbres? Il en découle un résumé détaillé de la littérature traitant des coûts d'entretien et du non-entretien selon diverses pratiques arboricoles couramment incluses dans les budgets municipaux (plantation, élagage, abattage, gestion des ravageurs et des maladies) et un bref résumé des coûts associés à certaines pratiques arboricoles moins considérées (incluant la gestion des risques liés aux arbres, l'arrosage, le paillage, la gestion de la fertilisation et des éléments nutritifs, le tuteurage, le haubanage flexible et rigide, la protection des arbres et la réparation des infrastructures). Les auteurs suggèrent que la documentation future devrait porter sur l'influence des stratégies d'entretien arboricole sur les coûts et les impacts pour les arbres, incluant la manière dont la fréquence, de l'intensité, de la durée et de l'ampleur des opérations d'entretien sont reliés à la structure, à la fonction et aux bénéfices générés par les arbres.

Zusamenfassung. Die existierende Literatur zum Thema: Urbane Forstwirtschaft ist am stärksten in ihrer Quantifizierung und Qualifikation der Vorteile der Bäume und ihrer Pflege, aber nicht in ihrer Fähigkeit, die Resultate mangelnder Investitionen zu untersuchen. Dieser Bericht präsentiert die Resultate einer Literaturrecherche über die „Kosten von nicht gepflegten Bäumen“, herausgegeben von dem ISA Wissenschaft und Forschungsausschuss. Die Autoren sammelten Literatur aus dem Bereich Arboristik und Urbaner Forstwirtschaft, um diese Frage zu beantworten: „Was sind die Erhaltungskosten von Stadtbäumen und urbanen Forstflächen?" und „Was sind die Kosten von nicht gepflegten Bäumen?" Hier liegt eine detaillierte Übersicht der Literatur zu Kosten der Erhaltung und
Kosten zum Ausgleich von Pflegemängeln für typische Pflegearbeiten, wie sie in den Budgets der Verwaltungen gewöhnlich vorkommen (Pflanzung, Schnittmaßnahmen, Entsorgung, Krankheitsund Schädlingsbekämpfung) und eine kurze Übersicht der damit assoziierten Kosten für weniger untersuchte Typen der Baumpflege (einschließlich Baumrisiko-Management, Bewässerung, Mulchauftrag, Düngung, Baumanbindung, Kronensicherung, Baumschutz und Reparaturen an der umgebenden Infrastruktur). Die Autoren schlagen vor, dass zukünftige Literatur sich zum Ziel setzen sollte, die Einflüsse von Pflegekonzepten auf die Kosten und die Wirkung auf die Bäume zu untersuchen, einschließlich einer Untersuchung, wie die Häufigkeit, Intensität, Daure und Ausmaß der Baumpflegeaktivitäten verbunden ist mit der Struktur, Funktion und Leistungen der Bäume.

Resumen. La literatura existente sobre el bosque urbano es fuerte en la cuantificación y cualificación de los beneficios y cuidado de los árboles y no tanto en su capacidad de evaluar los resultados de la falta de inversión en los árboles. Este trabajo presenta los resultados de una revisión de literatura sobre los "Costos de No Mantener los Árboles", encargados por el Science and Research Committee de la ISA. Los autores resumen la literatura desde el campo de la arboricultura/dasonomía urbana para responder a las preguntas: ¿Cuáles son los costos de mantenimiento de los árboles y el bosque urbano? Y, ¿Cuáles son los costos de no mantener los árboles? Se presenta aquí un resumen detallado de la literatura sobre los costos de mantenimiento y la falta de mantenimiento de los tipos de cuidado de los árboles que se suelen incluir en los presupuestos municipales (plantación, poda, remoción, manejo de plagas y enfermedades) y una breve revisión de los costos asociados con los cuidados de los árboles menos estudiados (incluyendo la gestión de riesgos; riego, acolchado, fertilización y manejo de elementos minerales; tutoreo, cableado y refuerzo; protección de los árboles; y reparación de infraestructura). Los autores sugieren que la literatura futura debería tener como objetivo examinar la influencia de los regímenes de mantenimiento en los costos y los resultados de los árboles, incluyendo el examen de cómo la frecuencia, intensidad, duración y alcance de las actividades de mantenimiento de los árboles están conectados a la estructura función y beneficios de los mismos. 